\title{
23. MAJOR- AND MINOR-ELEMENT CHEMISTRY OF ANTARCTIC CLAY-RICH SEDIMENTS: SITES 322, 323, AND 325, DSDP LEG 35
}

\author{
Thomas W. Donnelly and James L. Wallace, Department of Geological Sciences, \\ State University of New York at Binghamton, Binghamton, N.Y.

\section{INTRODUCTION}

\section{GENERAL CHEMICAL CHARACTERISTICS OF THE SEDIMENTS}

In an attempt to place some chemical constraints on models for the observed pore-water chemical and isotopic variations for three of the sites of Leg $35(322,323$, and 325), 72 sediment samples (Table 1) and 6 altered basalts (Table 2) were analyzed for major elements. The sediments were virtually all clay-rich and deposited at poorly known, but high rates. The chemistry largely reflects a terrigenous source. Secondary enrichments in certain elements were of special interest; contemporaneous enrichment in $\mathrm{Fe}, \mathrm{Mn}$, and $\mathrm{P}$ occurs in the basal sediments of Sites 323 and 322. The pore-water gradients in $\mathrm{Mg}$ and $\mathrm{K}$ at these sites require mineralogical sinks for these elements; both the sediments and some altered basalts of these sites were investigated with only limited success in an attempt to find such sinks, as well as a source for $\mathrm{Ca}$. Some minor elements $(\mathrm{Ba}, \mathrm{Sr}$, $\mathrm{Rb}, \mathrm{Y}, \mathrm{Zr}$ ) were also investigated (Table 3), but show no trend in concentration with depth.

\section{METHOD}

The "rapid" method in use in this laboratory has been described by Donnelly and Nalli (1973) and Donnelly and Wallace (1976). The method consists of a lithium borate fusion of a dried $50-\mathrm{mg}$ sample, with $\mathrm{Si}, \mathrm{Al}$, $\mathrm{Ti}$, and $\mathrm{P}$ determined colorimetrically, and $\mathrm{K}, \mathrm{Na}, \mathrm{Ca}$, $\mathrm{Mg}, \mathrm{Fe}$, and $\mathrm{Mn}$ determined by atomic absorption. $\mathrm{Cl}$ is determined by a separate mercuric nitrate titration. $\mathrm{Na}$, $\mathrm{Mg}, \mathrm{Ca}$, and $\mathrm{K}$ concentrations are adjusted to remove the pore-water contributions of these elements, using observed $\mathrm{Na} / \mathrm{Cl}, \mathrm{Mg} / \mathrm{Cl}, \mathrm{K} / \mathrm{Cl}$, and $\mathrm{Ca} / \mathrm{Cl}$ ratios (Gieskes and Lawrence, this volume).

Average absolute errors, expressed as a percent of the amount present and determined for USGS igneous rock standards run as "blind unknowns," are as follows: $\mathrm{SiO}_{2}, 3.9 \% ; \mathrm{TiO}_{2}, 4.1 \% ; \mathrm{Al}_{2} \mathrm{O}_{3}, 1.4 \% ; \mathrm{Fe}_{2} \mathrm{O}_{3}, 2.1 \% ; \mathrm{MnO}$, $27 \% ; \mathrm{MgO}, 4.9 \% ; \mathrm{CaO}, 3.5 \%$; $\mathrm{Na}_{2} \mathrm{O}, 2.4 \% ; \mathrm{K}_{2} \mathrm{O}, 3.5 \%$; and $\mathrm{P}_{2} \mathrm{O}_{5}, 10 \%$. The higher values for $\mathrm{Mn}$ and $\mathrm{P}$ reflect the low values in the USGS standards.

In order to normalize the values for the nonbiogenic sediments (removing biogenic carbonate or opal), values of $\mathrm{Mg}, \mathrm{Ti}, \mathrm{Na}, \mathrm{K}, \mathrm{Fe}$, and $\mathrm{Ca}$ are commonly reported as the atomic ratios $\mathrm{Ti} / \mathrm{Al}, \mathrm{Na} / \mathrm{Al}$, etc.

The presence of some minor elements $(\mathrm{Ba}, \mathrm{Sr}, \mathrm{Rb}, \mathrm{Zr}$, and $\mathrm{Y}$ ) was determined using $\mathrm{X}$-ray fluorescence (Mo tube, air path, LiF crystal, scintillation counter) on pressed pellets. USGS standards (G-2, GSP-1, BCR-1, W-1) served as standards. Mass absorption corrections were made in the style of Hower (1959). $\mathrm{Zr}$ was corrected for $\mathrm{Sr}$ and $\mathrm{Ba}$ interference and $\mathrm{Y}$ for $\mathrm{Rb}$ interference. Determinations of $\mathrm{Sr}, \mathrm{Rb}, \mathrm{Y}$, and $\mathrm{Zr}$ have an error of about $10 \mathrm{ppm}$, and $\mathrm{Ba}$ has an error of $20 \%$ of the amount present.
The three sites share two important similarities: sediments are primarily silt and clay with limited biogenic contribution, and all display high accumulation rates during deposition of the Oligocene and younger parts of the section.

The cored portion of Site 325 and the upper parts of Sites 322 (shallower than $510 \mathrm{~m}$ ) and 323 (shallower than $638 \mathrm{~m}$ ) are composed of terrigenous debris, with a minor admixture of opaline biogenic debris. The lower 4 meters of Site 322 and 63 meters of Site 323 are mineralogically distinct, consisting of iron and manganeseenriched montmorillonite, with several enriched minor elements. These lower sections resemble other wellknown iron-enriched basal sediments associated with spreading ridges (Boström, 1973, Boström et al., 1972; Boström and Peterson, 1966). Although their mineralogy is suggestive of a volcanic origin, we believe that they represent altered terrigenous debris with admixed $\mathrm{Fe}, \mathrm{Mn}, \mathrm{P}, \mathrm{Ba}, \mathrm{Y}$, and minor $\mathrm{Sr}$ and $\mathrm{Rb}$, which have undergone an otherwise isochemical mineralogical transformation. The content of certain conservative elements (especially $\mathrm{Ti}, \mathrm{Al}$, and $\mathrm{Zr}$ ) strongly suggests that the original chemical identity is maintained in the sediments of the upper and lower portions of these holes and that it is improbable that a significant part of the lower sediments could be of volcanic origin.

\section{SITE 323}

\section{Upper Part}

Because Site 323 displayed the largest number of geochemical problems and occupied the bulk of the attention of this cooperative study, it will be discussed first. The upper 638 meters is a terrigenous clay-mineral suite, with mixed-layer clays, kaolin, chlorite, quartz, feldspar, some opaline biogenic remains, and a recognizable glacial component. As Table 4 shows, Site 323 compares favorably with other clay-rich deep-sea sites in critical chemical ratios (based largely on unpublished data of this laboratory), as well as Clarke's "average shale" (Pettijohn, 1957) and Vinogradov and Ronov's (1956) average Russian "clay."

The Si/Al ratio is somewhat high, compared with typical Atlantic clays and the "average shale," but is not high when compared with many Pacific sediments. Microscopically recognizable biogenic opal is responsible for the higher $\mathrm{Si} / \mathrm{Al}$ ratio in many Pacific sites and much of the sediment in the upper part of Hole 323. However, the consistently high $\mathrm{Si} / \mathrm{Al}$ ratio, seen even in sediments with a trivial opaline fossil content, may indicate that postburial destruction of opaline fossils 
TABLE

Sediment Analyses

\begin{tabular}{|c|c|c|c|c|c|c|c|c|c|c|c|c|}
\hline $\begin{array}{c}\text { Sample } \\
\text { (Interval } \\
\text { in } \mathrm{cm} \text { ) }\end{array}$ & $\begin{array}{l}\text { Depth } \\
\text { (m) }\end{array}$ & $\mathrm{SiO}_{2}$ & $\mathrm{TiO}_{2}$ & $\mathrm{Al}_{2} \mathrm{O}_{3}$ & $\mathrm{Fe}_{2} \mathrm{O}_{3}{ }^{\mathrm{a}}$ & $\mathrm{MnO}$ & $\mathrm{MgO}^{\mathrm{b}}$ & $\mathrm{CaO}^{\mathrm{b}}$ & $\mathrm{Na}_{2} \mathrm{O}^{\mathrm{b}}$ & $\mathrm{K}_{2} \mathrm{O}^{\mathrm{b}}$ & $\mathrm{P}_{2} \mathrm{O}_{5}$ & $\mathrm{Cl}$ \\
\hline \multicolumn{13}{|l|}{ Site 322} \\
\hline $1-1,0$ & 76 & 62.9 & 0.82 & 13.7 & 6.99 & 0.09 & 3.33 & 2.94 & 4.69 & 2.09 & 0.23 & 0.73 \\
\hline $1-2,135$ & 79 & 64.1 & 0.70 & 11.7 & 6.12 & 0.06 & 3.04 & 2.46 & 2.17 & 1.82 & 0.11 & 0.63 \\
\hline $2-2,103$ & 193 & 66.1 & 0.64 & 12.9 & 5.63 & 0.16 & 2.56 & 3.03 & 2.32 & 1.83 & 0.18 & 0.55 \\
\hline $3-1,0$ & 295 & 60.6 & 0.75 & 14.3 & 7.41 & 0.14 & 3.13 & 3.22 & 2.72 & 2.13 & 0.17 & 0.80 \\
\hline $4-2,135$ & 355 & 62.6 & 0.74 & 15.8 & 5.52 & 0.13 & 2.21 & 4.88 & 3.52 & 1.33 & 0.21 & 0.39 \\
\hline $5-1,72$ & 392 & 60.3 & 0.85 & 15.6 & 6.34 & 0.44 & 2.64 & 3.28 & 2.88 & 2.35 & 0.27 & 0.34 \\
\hline $6-1,18$ & 439 & 59.2 & 0.70 & 14.7 & 5.96 & 0.92 & 2.65 & 2.24 & 2.45 & 2.77 & 0.33 & 0.28 \\
\hline $10-0,0$ & 486 & 59.5 & 0.76 & 15.6 & 6.40 & 0.18 & 3.25 & 2.78 & 2.72 & 2.66 & 0.25 & 0.41 \\
\hline $11-1,148$ & 506 & 67.1 & 0.73 & 14.7 & 4.63 & 0.06 & 2.60 & 3.89 & 3.64 & 1.46 & 0.17 & 0.36 \\
\hline $11-2,125$ & 508 & 63.4 & 0.71 & 14.5 & 4.26 & 0.08 & 2.59 & 3.65 & 3.80 & 1.64 & 0.17 & 0.34 \\
\hline $11-3,125$ & 509 & 66.5 & 0.73 & 14.3 & 4.80 & 0.08 & 2.47 & 3.77 & 3.72 & 1.79 & 0.17 & 0.37 \\
\hline $11-4,40$ & 510 & 61.5 & 1.04 & 16.4 & 4.85 & 0.10 & 2.11 & 3.79 & 3.86 & 2.32 & 0.23 & 0.37 \\
\hline $11-4,62$ & 510 & 58.1 & 0.71 & 14.2 & 8.89 & 0.12 & 3.66 & 0.95 & 2.64 & 4.20 & 0.11 & 0.25 \\
\hline $11-4,122$ & 511 & 56.6 & 0.85 & 13.6 & 8.47 & 0.23 & 3.52 & 1.42 & 2.21 & 2.84 & 0.24 & 0.26 \\
\hline $11-4,135$ & 511 & 51.8 & 0.80 & 14.6 & 8.36 & 0.37 & 3.30 & 1.61 & 2.07 & 3.04 & 0.33 & 0.30 \\
\hline $11-5,18$ & 511 & 58.2 & 0.93 & 14.9 & 8.17 & 0.26 & 3.20 & 2.04 & 2.24 & 3.31 & 0.45 & 0.60 \\
\hline $11-5,110$ & 512 & 57.5 & 0.86 & 15.1 & 4.50 & 0.72 & 2.81 & 1.34 & 2.18 & 4.26 & 0.30 & 0.30 \\
\hline $11-6,30$ & 513 & 56.7 & 0.73 & 15.2 & 7.62 & 1.17 & 2.83 & 1.09 & 1.81 & 4.44 & 0.40 & 0.38 \\
\hline $11-6,103$ & 514 & 55.8 & 0.70 & 15.5 & 8.40 & 1.18 & 2.65 & 0.88 & 1.65 & 4.65 & 0.40 & 0.40 \\
\hline $11, \mathrm{CC}^{\mathrm{c}}$ & 514 & 54.6 & 0.66 & 15.2 & 9.14 & 1.50 & 2.63 & 1.13 & 1.68 & 4.51 & 0.55 & 0.51 \\
\hline $11, \mathrm{CC}^{\mathrm{d}}$ & 514 & 55.7 & 0.73 & 15.6 & 8.09 & 1.04 & 2.69 & 1.20 & 1.55 & 3.57 & 0.54 & 0.65 \\
\hline $11, \mathrm{CC}^{\mathrm{e}}$ & 514 & 57.2 & 0.71 & 15.5 & 8.13 & 0.90 & 2.76 & 0.99 & 1.68 & 4.71 & 0.41 & 0.38 \\
\hline \multicolumn{13}{|l|}{ Site 323} \\
\hline $1-5,0$ & 82 & 64.9 & 0.62 & 13.0 & 6.85 & 0.16 & 2.65 & 1.29 & 1.94 & 2.48 & 0.15 & 0.89 \\
\hline $2-1,93$ & 162 & 62.8 & 0.64 & 13.2 & 6.29 & 0.18 & 2.45 & 1.15 & 1.90 & 2.90 & 0.14 & 0.72 \\
\hline $3, \mathrm{CC}$ & 266 & 60.0 & 0.70 & 14.1 & 7.68 & 0.09 & 2.77 & 1.90 & 2.53 & 2.42 & 0.32 & 0.23 \\
\hline $4, \mathrm{CC}$ & 322 & 62.8 & 0.67 & 14.6 & 5.76 & 0.32 & 2.39 & 1.90 & 2.59 & 2.75 & 0.01 & 0.40 \\
\hline $7-3,31$ & 364 & 69.0 & 0.75 & 13.9 & 6.26 & 0.16 & 2.38 & 1.64 & 2.17 & 2.75 & 0.19 & 0.50 \\
\hline $8-1,118^{f}$ & 409 & 80.9 & 0.25 & 5.5 & 2.34 & nil & 0.79 & 0.50 & 0.87 & 1.24 & 0.08 & 0.10 \\
\hline $8, \mathrm{CC}_{\mathrm{f}}$ & 418 & 62.1 & 0.75 & 14.5 & 6.05 & 0.12 & 2.55 & 1.86 & 2.59 & 2.82 & 0.45 & 0.50 \\
\hline $8, C C^{f}$ & 418 & 79.9 & 0.31 & 6.9 & 3.08 & 0.02 & 1.04 & 0.59 & 0.98 & 1.51 & 0.10 & 0.05 \\
\hline $9-2,0$ & 457 & 51.7 & 0.52 & 12.7 & 5.11 & 0.31 & 2.87 & 1.47 & 2.01 & 1.70 & 0.18 & 0.81 \\
\hline $9-2,(\# 1)^{\mathrm{g}}$ & 458 & 59.4 & 0.83 & 14.9 & 7.34 & 0.05 & 2.67 & 1.62 & 2.54 & 3.01 & 0.17 & 0.40 \\
\hline $9-2,(\# 3)^{g}$ & 458 & 59.2 & 0.84 & 15.0 & 6.74 & 0.05 & 2.60 & 1.52 & 2.40 & 3.12 & 0.17 & 0.37 \\
\hline $9-2,(\# 8)^{1}$ & 458 & & 0.48 & 9.9 & 4.62 & 0.01 & 1.58 & 0.84 & 1.55 & 1.61 & 0.11 & 0.26 \\
\hline $9, \mathrm{CC}$ & 465 & 64.3 & 0.63 & 13.8 & 5.30 & 0.18 & 2.24 & 1.15 & 1.94 & 3.11 & 0.21 & 0.38 \\
\hline $10-1,95$ & 504 & 61.1 & 0.46 & 10.0 & 3.77 & 0.02 & 1.43 & 0.74 & 1.40 & 2.20 & 0.11 & 0.38 \\
\hline $10-3,0$ & 506 & 63.0 & 0.73 & 157 & 6.33 & 0.14 & 2.59 & 1.63 & 1.98 & 2.59 & 0.18 & 0.95 \\
\hline $11-1,0$ & 550 & 63.8 & 0.75 & 15.4 & 5.45 & 0.14 & 2.42 & 0.99 & 1.89 & 3.55 & 0.22 & 0.35 \\
\hline $12-1,135$ & 599 & 63.3 & 0.76 & 16.2 & 5.74 & 0.10 & 2.47 & 0.94 & 1.86 & 3.88 & 0.18 & 0.35 \\
\hline $13-5,127$ & 624 & 61.8 & 0.83 & 14.6 & 6.49 & 0.20 & 2.44 & 1.13 & 1.93 & 3.28 & 0.28 & 0.30 \\
\hline $13, \mathrm{CC}^{\mathrm{h}}$ & 626 & 66.9 & 0.85 & 13.8 & 5.51 & 0.24 & 2.11 & 0.87 & 1.74 & 3.55 & 0.28 & 0.32 \\
\hline $13, \mathrm{CC}^{\mathrm{i}}$ & 626 & 63.4 & 0.76 & 14.5 & 6.24 & 0.20 & 3.38 & 1.82 & 2.33 & 3.59 & 0.22 & 0.27 \\
\hline $14-2,11$ & 638 & 68.8 & 0.74 & 14.0 & 4.75 & 0.17 & 1.87 & 0.79 & 1.84 & 3.15 & 0.19 & 0.22 \\
\hline $14-2,60$ & 638 & 67.6 & 0.71 & 13.7 & 4.30 & 0.02 & 2.00 & 0.69 & 1.62 & 3.33 & 0.16 & 0.26 \\
\hline $14-2,102$ & 639 & 51.1 & 0.74 & 15.8 & 10.54 & 1.81 & 2.53 & 1.95 & 1.89 & 2.61 & 0.93 & 0.40 \\
\hline $14, \mathrm{CC}$ & 646 & 50.2 & 0.77 & 15.5 & 10.25 & 1.93 & 2.59 & 1.84 & 1.87 & 2.34 & 0.28 & 0.34 \\
\hline $15-1,142$ & 656 & 43.0 & 0.71 & 14.6 & 16.5 & 5.14 & 2.72 & 1.21 & 1.53 & 2.74 & 0.50 & 0.58 \\
\hline $15-3,75$ & 659 & 51.9 & 0.74 & 16.5 & 11.0 & 1.61 & 2.43 & 1.34 & 1.71 & 3.23 & 0.46 & 0.39 \\
\hline $15-6,49$ & 663 & 30.7 & 0.46 & 10.9 & 8.11 & 1.84 & 1.39 & 21.7 & 0.85 & 2.13 & 0.27 & 0.35 \\
\hline $16-1,54$ & 665 & 28.9 & 0.40 & 8.5 & 4.64 & 1.88 & 1.47 & 27.0 & 0.89 & 1.98 & 0.14 & 0.22 \\
\hline $16-2,19$ & 666 & 35.2 & 0.46 & 9.7 & 5.72 & 0.77 & 1.83 & 21.8 & 1.12 & 204 & 0.14 & 0.21 \\
\hline $16-2,56$ & 667 & 37.6 & 0.54 & 10.2 & 6.06 & 0.54 & 2.24 & 18.8 & 1.25 & 2.18 & 0.14 & 0.22 \\
\hline $16-2,143$ & 667 & 57.6 & 0.71 & 15.0 & 7.72 & 0.60 & 3.35 & 1.16 & 1.86 & 3.03 & 0.19 & 0.54 \\
\hline $16-3,29$ & 668 & 57.0 & 0.77 & 13.8 & 8.46 & 0.73 & 3.41 & 1.40 & 1.96 & 2.28 & 0.33 & 0.53 \\
\hline $16-3,130$ & 669 & 52.1 & 0.69 & 13.6 & 10.7 & 1.40 & 2.90 & 1.29 & 2.02 & 2.06 & 0.21 & 0.30 \\
\hline $16-4,71$ & 670 & 56.5 & 0.74 & 14.1 & 10.5 & 0.52 & 2.53 & 1.80 & 2.41 & 2.66 & 0.41 & 0.24 \\
\hline $17-6,133$ & 683 & 55.3 & 0.74 & 14.7 & 9.03 & 0.49 & 2.42 & 1.80 & 2.04 & 2.80 & 0.55 & 0.25 \\
\hline $18-2,131$ & 696 & 58.1 & 0.70 & 15.2 & 7.37 & 0.14 & 2.01 & 1.19 & 2.28 & 3.51 & 0.16 & 0.24 \\
\hline $18-4,9$ & 698 & 59.8 & 0.65 & 13.6 & 7.30 & 0.12 & 1.83 & 1.05 & 2.66 & 2.75 & 0.09 & 0.29 \\
\hline $18-5,148$ & 700 & 52.3 & 0.55 & 12.0 & 14.4 & 0.46 & 2.87 & 1.67 & 1.84 & 2.62 & 0.44 & 0.25 \\
\hline $18-6,4$ & 701 & 54.8 & 0.56 & 11.2 & 9.74 & 0.26 & 2.97 & 1.59 & 1.74 & 2.43 & 0.45 & 0.30 \\
\hline
\end{tabular}


TABLE 1 - Continued

\begin{tabular}{|c|c|c|c|c|c|c|c|c|c|c|c|c|}
\hline $\begin{array}{c}\text { Sample } \\
\text { (Interval } \\
\text { in } \mathrm{cm} \text { ) }\end{array}$ & $\begin{array}{l}\text { Depth } \\
\text { (m) }\end{array}$ & $\mathrm{SiO}_{2}$ & $\mathrm{TiO}_{2}$ & $\mathrm{Al}_{2} \mathrm{O}_{3}$ & $\mathrm{Fe}_{2} \mathrm{O}_{3}{ }^{\mathrm{a}}$ & $\mathrm{MnO}$ & $\mathrm{MgO}^{\mathrm{b}}$ & $\mathrm{CaO}^{\mathrm{b}}$ & $\mathrm{Na}_{2} \mathrm{O}^{\mathrm{b}}$ & $\mathrm{K}_{2} \mathrm{O}^{\mathrm{b}}$ & $\mathrm{P}_{2} \mathrm{O}_{5}$ & $\mathrm{Cl}$ \\
\hline \multicolumn{13}{|l|}{ Site 325} \\
\hline $1-3,35$ & 37 & 66.9 & 0.74 & 15.0 & 6.10 & 0.18 & 2.65 & 3.15 & 2.82 & 2.11 & 0.20 & 0.38 \\
\hline $2-1,143$ & 168 & 63.4 & 0.75 & 14.5 & 5.85 & 0.16 & 2.60 & 3.18 & 2.92 & 2.02 & 0.21 & 0.28 \\
\hline $3-2,0$ & 178 & 65.4 & 0.74 & 14.0 & 5.85 & 0.07 & 2.69 & 3.47 & 2.99 & 1.88 & 0.19 & 0.33 \\
\hline $3-3,135$ & 181 & 61.8 & 0.65 & 13.6 & 5.29 & 0.14 & 2.32 & 3.48 & 3.07 & 1.75 & 0.20 & 0.29 \\
\hline $5-1,117$ & 406 & 62.9 & 0.77 & 14.7 & 6.25 & 0.16 & 2.76 & 2.78 & 2.56 & 2.44 & 0.20 & 0.34 \\
\hline $6-1,138$ & 482 & 70.8 & 0.74 & 14.7 & 6.16 & 0.18 & 2.64 & 3.65 & 2.45 & 1.74 & 0.21 & 0.47 \\
\hline $7-2,140$ & 521 & 63.3 & 0.72 & 14.0 & 6.42 & 0.06 & 2.90 & 3.06 & 2.28 & 2.34 & 0.17 & 0.42 \\
\hline $8-2,145$ & 615 & 63.7 & 0.71 & 13.9 & 6.79 & 0.06 & 2.63 & 3.01 & 2.50 & 2.19 & 0.18 & 0.39 \\
\hline $8, \mathrm{CC}$ & 622 & 61.1 & 0.75 & 15.2 & 7.29 & 0.09 & 2.77 & 3.52 & 2.69 & 2.34 & 0.16 & 0.32 \\
\hline $9-1,133$ & 642 & 54.8 & 0.70 & 14.3 & 7.65 & 0.16 & 3.59 & 2.95 & 2.71 & 1.96 & 0.21 & 0.34 \\
\hline $10-2,0$ & 710 & 58.9 & 0.79 & 16.0 & 7.43 & 0.14 & 3.19 & 3.56 & 3.43 & 1.93 & 0.21 & 0.32 \\
\hline
\end{tabular}

Note: James L. Wallace, Analyst.

${ }^{\mathrm{a}} \mathrm{Total} \mathrm{Fe}$ as $\mathrm{Fe}_{2} \mathrm{O}_{3}$.

${ }^{\mathrm{b}}$ Corrected for pore-water $\mathrm{Mg}, \mathrm{Ca}, \mathrm{Na}$, and $\mathrm{K}$

c"Within $20 \mathrm{~cm}$ of basalt."

d" $10 \mathrm{~cm}$ from basalt."

e" $20 \mathrm{~cm}$ from basalt."

$\mathrm{f}_{\text {Chert. }}$

g Claystone.

h"Top."

i"Bottom."

TABLE 2

Basalt Analyses

\begin{tabular}{|c|c|c|c|c|c|c|c|c|c|c|c|c|c|c|c|}
\hline $\begin{array}{c}\text { Sample } \\
\text { (Interval } \\
\text { in } \mathrm{cm} \text { ) }\end{array}$ & $\mathrm{SiO}_{2}$ & $\mathrm{TiO}_{2}$ & $\mathrm{Al}_{2} \mathrm{O}_{3}$ & $\mathrm{Fe}_{2} \mathrm{O}_{3}$ & $\mathrm{FeO}$ & $\mathrm{Fe}^{\mathrm{a}}$ & $\mathrm{MnO}$ & $\mathrm{MgO}$ & $\mathrm{CaO}$ & $\mathrm{Na}_{2} \mathrm{O}^{\mathrm{b}}$ & $\mathrm{K}_{2} \mathrm{O}$ & $\mathrm{P}_{2} \mathrm{O}_{5}$ & $\mathrm{H}_{2} \mathrm{O}+$ & $\mathrm{H}_{2} \mathrm{O}-$ & $\mathrm{Cl}$ \\
\hline \multicolumn{16}{|l|}{ Site 322} \\
\hline $\begin{array}{l}12-1, \\
12-1,105 \\
13-1,173\end{array}$ & $\begin{array}{l}48.97 \\
49.5 \\
49.1\end{array}$ & $\begin{array}{l}1.54 \\
1.52 \\
2.25\end{array}$ & $\begin{array}{l}16.14 \\
16.3 \\
16.3\end{array}$ & $\begin{array}{l}5.00 \\
6.81 \\
8.12\end{array}$ & $\begin{array}{l}3.88 \\
4.08 \\
3.76\end{array}$ & $\begin{array}{l}54 \\
60 \\
66\end{array}$ & $\begin{array}{l}0.14 \\
0.16 \\
0.29\end{array}$ & $\begin{array}{l}6.14 \\
6.11 \\
5.18\end{array}$ & $\begin{array}{l}11.71 \\
11.51 \\
10.57\end{array}$ & $\begin{array}{l}2.54 \\
2.54 \\
2.85\end{array}$ & $\begin{array}{l}0.81 \\
0.74 \\
0.65\end{array}$ & $\begin{array}{l}0.20 \\
0.16 \\
0.25\end{array}$ & $\begin{array}{l}0.93 \\
\text { n.d. } \\
\text { n.d. }\end{array}$ & $\begin{array}{l}2.28 \\
\text { n1.d. } \\
\text { n.d. }\end{array}$ & $\begin{array}{l}\text { n.d. }^{\mathrm{c}} \\
0.05^{\mathrm{d}} \\
0.08^{\mathrm{d}}\end{array}$ \\
\hline \multicolumn{16}{|l|}{ Site 323} \\
\hline $\begin{array}{l}19-4, \\
19-2,144^{\mathrm{e}} \\
19-2,144^{\mathrm{f}} \\
18-6,14^{\mathrm{e}} \\
18-6,14^{\mathrm{f}}\end{array}$ & $\begin{array}{l}48.20 \\
51.0 \\
46.8 \\
52.0 \\
51.2\end{array}$ & $\begin{array}{l}2.89 \\
3.22 \\
2.85 \\
2.84 \\
3.08\end{array}$ & $\begin{array}{l}13.77 \\
15.2 \\
13.5 \\
19.7 \\
19.8\end{array}$ & $\begin{array}{r}6.12 \\
6.80 \\
10.89 \\
7.44 \\
4.82\end{array}$ & $\begin{array}{l}5.95 \\
3.73 \\
6.02 \\
1.00 \\
0.36\end{array}$ & $\begin{array}{l}48 \\
62 \\
62 \\
87 \\
92\end{array}$ & $\begin{array}{l}0.23 \\
0.30 \\
0.49 \\
0.21 \\
0.53\end{array}$ & $\begin{array}{l}5.81 \\
5.65 \\
5.15 \\
1.64 \\
1.17\end{array}$ & $\begin{array}{r}10.43 \\
9.92 \\
9.16 \\
4.78 \\
8.94\end{array}$ & $\begin{array}{l}2.62 \\
3.31 \\
2.94 \\
3.35 \\
3.64\end{array}$ & $\begin{array}{l}0.53 \\
0.72 \\
0.62 \\
2.55 \\
2.10\end{array}$ & $\begin{array}{l}0.23 \\
0.32 \\
0.30 \\
0.31 \\
0.44\end{array}$ & $\begin{array}{l}1.03 \\
\text { n.d. } \\
\text { n.d. } \\
\text { n.d. } \\
\text { n.d. }\end{array}$ & $\begin{array}{l}2.67 \\
\text { n.d. } \\
\text { n.d. } \\
\text { n.d. } \\
\text { n.d. }\end{array}$ & $\begin{array}{l}\text { n.d. }^{\mathrm{c}} \\
0.05^{\mathrm{d}} \\
0.05^{\mathrm{d}} \\
0.21^{\mathrm{d}} \\
0.27^{\mathrm{d}}\end{array}$ \\
\hline
\end{tabular}

Note: n.d. $=$ not determined

${ }^{a}$ Atomic ratio ferric iron/total iron.

${ }^{\mathrm{b}}$ Corrected for pore water $\mathrm{Na}$ where $\mathrm{Cl}$ has been determined.

${ }^{\mathrm{c}}$ Smithsonian Institution, Julie Norberg Analyst.

${ }^{\mathrm{d}}$ State University of New York at Binghamton, Max Budd, Analyst.

e"Fresh."

f"Altered."

leaves a chemical indication (the higher $\mathrm{Si} / \mathrm{Al}$ ratio) of their former presence.

The ratios $\mathrm{Fe} / \mathrm{Al}$ (Figure 1) and $\mathrm{Mg} / \mathrm{Al}$ (Figure 2) are not exceptional compared with other pelagic sediments. The ratio K/Al (Figure 3) of the upper part of Site 323 is the highest we have yet found for pelagic clays and apparently reflects a high illite content. The reason K/Al ratios are lower in pelagic clays than in continental shales (Table 4) remains one of the more interesting problems in pelagic sedimentary geochemistry.
The $\mathrm{Ca} / \mathrm{Al}$ and $\mathrm{Na} / \mathrm{Al}$ ratios in sediments of upper part of Hole 323 are low compared with Sites 322 and 325. The X-ray mineralogy determinations show a lower plagioclase/quartz ratio for this site (Zemmels and Cook, this volume). Apparently a significant part of the $\mathrm{Ca}$ and $\mathrm{Na}$ is present in plagioclase, whose lower content at this site is reflected in the smaller amounts of these elements.

The ratios $\mathrm{Si} / \mathrm{Al}$ and $\mathrm{Fe} / \mathrm{Al}$ in upper part of Hole 323 both increase upward (Figures 3 and 1), possibly re- 
TABLE 3

Minor-Element Determinations by

X-Ray Fluorescence (Values in ppm)

\begin{tabular}{lrlllr}
\hline $\begin{array}{c}\text { Sample } \\
\text { (Interval } \\
\text { in cm) }\end{array}$ & $\mathrm{Ba}$ & $\mathrm{Zr}$ & $\mathrm{Y}$ & $\mathrm{Sr}$ & $\mathrm{Rb}$ \\
\hline Site 322 & & & & & \\
$1-2,135$ & n.d. & 47 & n.d. & 111 & 69 \\
$3-1,0$ & 860 & 58 & n.d. & 165 & 34 \\
$4-2,135$ & 540 & 71 & n.d. & 217 & 36 \\
$5-1,72$ & n.d. & 77 & n.d. & 173 & n.d. \\
$6-1,18$ & 1650 & 73 & 16 & 124 & 74 \\
$10-0,0$ & 740 & 59 & 15 & 161 & 31 \\
$11-4,62$ & 1160 & 58 & n.d. & 66 & 90 \\
$11-4,135$ & 2100 & 61 & 14 & 57 & 56
\end{tabular}

Site 323

$\begin{array}{lrrrrr}1-5,0 & 1140 & 62 & \text { n.d. } & 87 & 59 \\ 3, \text { CC } & 1190 & 79 & \text { n.d. } & 122 & 65 \\ 4, \text { CC } & 290 & 60 & 27 & 102 & 54 \\ 7-3,31 & 1320 & 83 & 13 & 106 & 62 \\ 9-2,0 & 780 & 60 & 6 & 102 & 52 \\ 9, \text { CC } & 740 & 55 & 14 & 101 & 74 \\ 10-3,0 & 1960 & 91 & 24 & 140 & 67 \\ 11-1,0 & 310 & 77 & \text { n.d. } & 89 & 81 \\ 12-1,135 & 1620 & 61 & 29 & 66 & 67 \\ 13-5,127 & 610 & 111 & 21 & 76 & 62 \\ 14-2,11 & 780 & 119 & 21 & 65 & 66 \\ 14-2,60 & 210 & 97 & 16 & 17 & 80 \\ 14-2,102 & 1310 & 109 & 87 & 139 & 134 \\ 14, \text { CC } & 860 & 93 & 62 & 150 & 28 \\ 15-3,75 & 910 & 113 & 28 & 209 & 55 \\ 16-1,54 & 670 & 44 & \text { n.d. } & 246 & 23 \\ 16-2,19 & 440 & 65 & 15 & 273 & 37 \\ 16-2,56 & \text { n.d. } & 64 & \text { n.d. } & 193 & \text { n.d. } \\ 16-2,143 & 310 & 52 & 6 & 52 & 34 \\ 16-3,29 & 300 & 75 & 22 & 70 & 34 \\ 16-3,130 & 1050 & 72 & 24 & 88 & 30 \\ 16-4,71 & 770 & 85 & 31 & 108 & 41 \\ 17-6,133 & 770 & 70 & 20 & 131 & 46 \\ 18-4,9 & 5800 & 79 & 24 & 213 & 61 \\ 18-5,148 & 25000 & \text { int. } & 29 & 178 & 35 \\ 18-6,4 & 8400 & 67 & 32 & 147 & 29\end{array}$

Site 325

$\begin{array}{lrrrrr}1-3,35 & 570 & 120 & \text { n.d. } & 172 & 41 \\ 2-1,143 & 610 & 79 & 6 & 163 & 28 \\ 3-3,135 & 800 & 81 & 11 & 164 & 21 \\ 5-1,117 & 270 & 70 & \text { n.d. } & 172 & 38 \\ 8-2,145 & 500 & 56 & \text { n.d. } & 115 & 42 \\ 8, \text { CC } & 930 & 63 & \text { n.d. } & 170 & 30 \\ 9-1,113 & 820 & 53 & \text { n.d. } & 122 & 41 \\ 10-2,0 & 720 & 39 & \text { n.d. } & 193 & 25\end{array}$

Note: n.d. $=$ not determined, low value $;$ int. $=$ not determined; interference.

flecting long-term variations in the composition of the clays, and a possible increase in opaline fossil supply during deposition of the younger sediments.

\section{Lower Part}

At about 638 meters subbottom at Site 323 a striking mineralogical and textural change occurs in the sediments. The lower sediment is locally enriched in $\mathrm{Fe}$, $\mathrm{Mn}$, and several minor elements and is mineralogically a mixture of bentonitic montmorillonite and other authigenic minerals. The secondary nature of this sedi- ment is undoubted; the nature of the original sediment is not, however, immediately clear.

Except for the obviously secondarily enriched elements discussed below, the more conservative elements occur above and below the boundary in very similar ratios. Thus, the $\mathrm{Si} / \mathrm{Al}, \mathrm{Ti} / \mathrm{Al}$ (Figure 4), K/Al, $\mathrm{Mg} / \mathrm{Al}$ ratios and the content of $\mathrm{Zr}$ are very similar (Table 3). More significant, these ratios occur well within the range of other pelagic clays of nonvolcanic origin (except for the higher $\mathrm{K} / \mathrm{Al}$ ratio, which is, however, virtually the same as in the upper part of the sediment at Site 323). The higher $\mathrm{Si} / \mathrm{Al}$ ratio at the base of the lower part of the sequence at Site 323 is due to the presence of increased number of radiolarians as noted in the Site 323 report (this volume).

It is difficult to identify the original material which was ultimately transformed to a bentonitic montmorillonite. A paucity of recognizable detrital grains lends no support to either a volcanic or a terrigenous source. If the original material was volcanic, then a chemical indication of this could be sought. There are two broad groups of volcanics which might supply a sufficient amount of debris $(63 \mathrm{~m})$ to a pelagic site: (1) oceanic intrabasinal basalt and (2) the island-arc volcanic suite. The former is a tholeiitic suite with some alkalic differentiation. The latter, in CretaceousTertiary examples, is dominantly andesitic (pyroxene or hornblende) with a smaller fraction of calcalkaline basalt, and very minor amounts of rhyolite and dacite.

Intrabasinal basalts can be ruled out as the source rock in the present case because the ratio of the two critical elements, $\mathrm{Ti} / \mathrm{Al}$, is significantly higher in these basalts than in the sediments from the lower part of Hole 323 (Figure 5). More differentiated basalts have even higher $\mathrm{Ti} / \mathrm{Al}$ ratios (extending beyond the right side of Figure 5). The possibility of postdepositional changes in basaltic ash resulting in lower $\mathrm{Ti} / \mathrm{Al}$ ratios approaching those characteristic of Site 323 sediments, must also be considered. In spite of the very low solubilities of $\mathrm{Ti}$ and $\mathrm{Al}$ in seawater some recent investigations (Hart, 1970; McKelvey and Fleet, 1974; Melson, 1973; Melson and Thompson, 1973; Thompson, 1973) suggest that some components of basalt (especially glass) may absorb $\mathrm{Ti}$ (whose source is not known) during low-temperature alteration. However, this effect would move the $\mathrm{Ti} / \mathrm{Al}$ ratio away from the observed values for the Leg 35 sediments. Furthermore, the $\mathrm{Ti}$ in these cases might be locally derived, leaving $\mathrm{Ti}$ depleted zones and the $\mathrm{Ti} / \mathrm{Al}$ ratio, on the average, unchanged.

The possibility that the lower Site 323 sediment represents an island-arc suite is not so easily dismissed. The general chemical similarity between the "average shale" and "average andesite" is well known. However, little is known about the composition of the "average pelagic volcanic contribution" from island arcs and continental margin orogenic belts. The differences in explosivity of the volcanic types suggests that calcalkaline basalt would be less abundant and the more siliceous ignimbrites would be more abundant, relative to their occurrences near the eruptive centers. Further, numerous studies of ash layers (Bowles et al., 1973; D. Ninkovich, personal communication) show a 
TABLE 4

Critical Chemical Ratios for Clay-Rich Sediments

\begin{tabular}{lcccccl}
\hline Site & Si/Al & $\mathrm{Ti} / \mathrm{Al}$ & $\mathrm{Fe} / \mathrm{Al}$ & $\mathrm{Mg} / \mathrm{Al}$ & $\mathrm{K} / \mathrm{Al}$ & \multicolumn{1}{c}{ Reference } \\
\hline Caribbean and Western Atlantic & & & & & \\
27 (14 samples) & 2.20 & 0.026 & 0.237 & 0.120 & 0.123 & Unpublished \\
29 (27 samples) & 2.16 & 0.024 & 0.243 & 0.136 & 0.136 & Unpublished \\
30 (17 samples) & 2.58 & 0.030 & 0.323 & 0.189 & 0.142 & Unpublished \\
31 (16 samples) & 2.40 & 0.025 & 0.253 & 0.173 & 0.142 & Unpublished \\
148 (27 samples) & 2.24 & 0.026 & 0.244 & 0.124 & 0.131 & Unpublished \\
149 (20 samples) & $2.31^{\mathrm{a}}$ & 0.025 & 0.256 & $0.185^{\mathrm{a}}$ & 0.130 & Donnelly and Nalli, 1973 \\
154 (17 samples) & 2.33 & 0.029 & 0.286 & 0.210 & 0.124 & Unpublished \\
& & & & & & \\
Pacific & & & & & & \\
34 (44 samples) & 3.85 & 0.031 & 0.317 & 0.315 & 0.177 & Unpublished \\
84 (15 samples) & 3.58 & 0.033 & 0.270 & 0.256 & 0.110 & Unpublished \\
166 (18 samples) & & 0.024 & 0.284 & 0.296 & 0.183 & Unpublished \\
192 (24 samples) & $4.11^{\mathrm{c}}$ & 0.032 & 0.316 & 0.228 & 0.164 & Unpublished \\
283 (19 samples) & 3.96 & 0.034 & 0.387 & 0.162 & 0.142 & Unpublished \\
322 upper (6 samples) & 3.85 & 0.034 & 0.292 & 0.259 & 0.150 & This study \\
322 middle (6 samples) & 3.56 & 0.033 & 0.226 & 0.221 & 0.151 & This study \\
322 lower (10 samples) & 2.90 & 0.033 & 0.342 & 0.256 & 0.286 & This study \\
323 upper (19 samples) & 3.92 & 0.032 & 0.270 & 0.218 & 0.225 & This study \\
323 lower (17 samples) & 3.15 & 0.031 & 0.449 & 0.236 & 0.211 & This study \\
325 (11 samples) & 3.68 & 0.032 & 0.284 & 0.243 & 0.154 & This study \\
Clarke's average shale & 3.20 & 0.027 & 0.280 & 0.114 & 0.228 & Pettijohn, 1957 \\
Average Russian "clay" & 2.85 & 0.033 & 0.274 & 0.158 & 0.250 & Vinogradov and Ronov, 1956 \\
\hline
\end{tabular}

${ }^{\mathrm{a}}$ Upper 17 cores only; values omitted for more opaline lower cores.

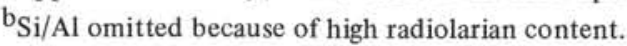

${ }^{c}$ Upper 9 cores only; values omitted for more opaline lower cores.

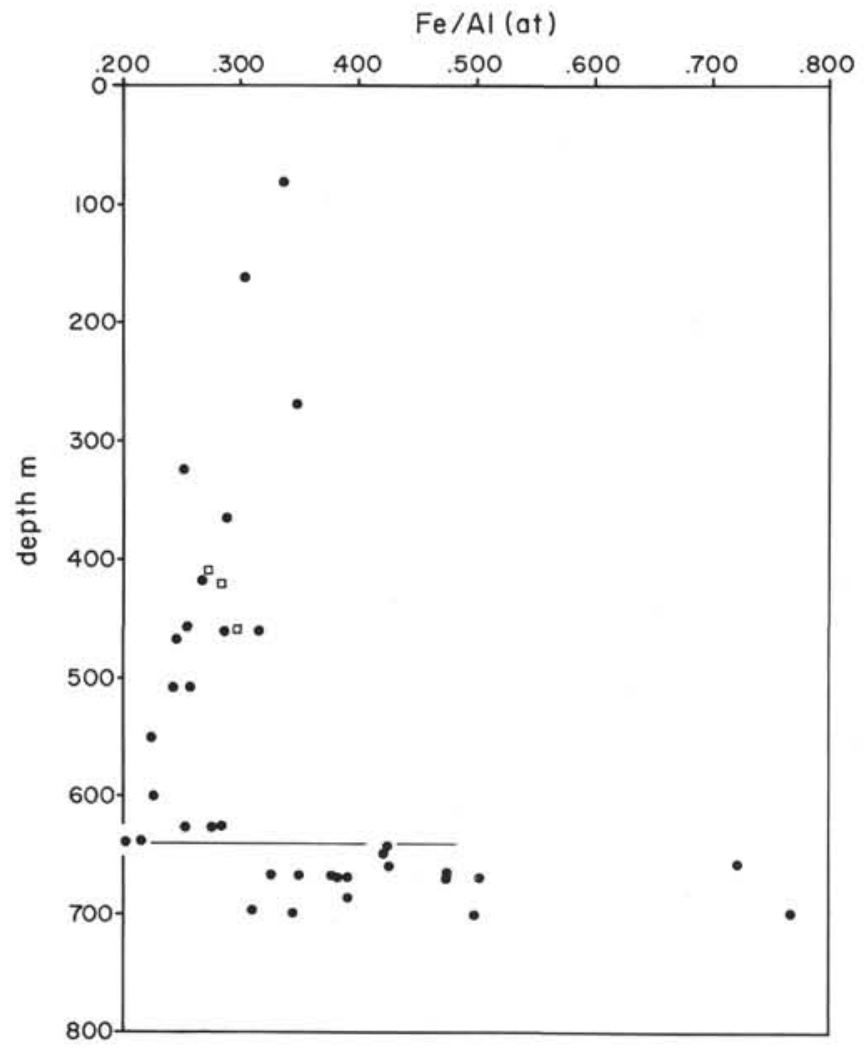

Figure 1. Graph showing $\mathrm{Fe} / \mathrm{Al}$ (atomic) versus depth for

Site 323. Lines show mineralogical change at 638 meters.

tion of siliceous glass. If this material is a significant contributor to pelagic sediment, then its low $\mathrm{Ti} / \mathrm{Al}$ ratio would be an effective criterion to discriminate between a volcanic and terrigenous (shale) source.

Assuming that there is no difference between the "average erupted island-arc magma" and the "average pelagic contribution from island-arcs" then discrimination based on chemical content is less reliable. Pending a more comprehensive investigation of the chemical characteristics of pelagic ash of island-arc origin, it should be noted that the values of the Ti/Al ratio of the Site 323 sediments (as well as for Sites 322 and 325) in addition to being somewhat more $\mathrm{Ti}$ rich are more restricted than would be characteristic for island-arc volcanics (Figure 6).

In summary, the general chemical character (especially the $\mathrm{Ti} / \mathrm{Al}$ ratio) rules out the possibility of a significant basaltic contribution to the Site 323 sediments. The chemical similarity of the upper and lower sections and the nearly invariant $\mathrm{Ti} / \mathrm{Al}$ ratio strongly suggest that the lower and upper parts are of the same terrigenous origin and are not of island-arc volcanic origin. However, our present knowledge of the character of these ashes in deep-sea sediments is inadequate to definitely allow distinction between volcanic and terrigenous sources.

\section{Iron Enrichment of Lower Site 323}

The lower 63 meters at Site 323 is strikingly $\mathrm{Fe}$ and $\mathrm{Mn}$ enriched. The general character of this enrichment is very similar to that described by Boström and Peterson (1966), Boström (1973), and Boström et al. (1972). Its occurrence at Site 323 is somewhat exceptional in that it extends to 63 meters above the base of the sediments, and is more pronounced at the top of this interval. As the data of Table 3 show, enrichment by several related 


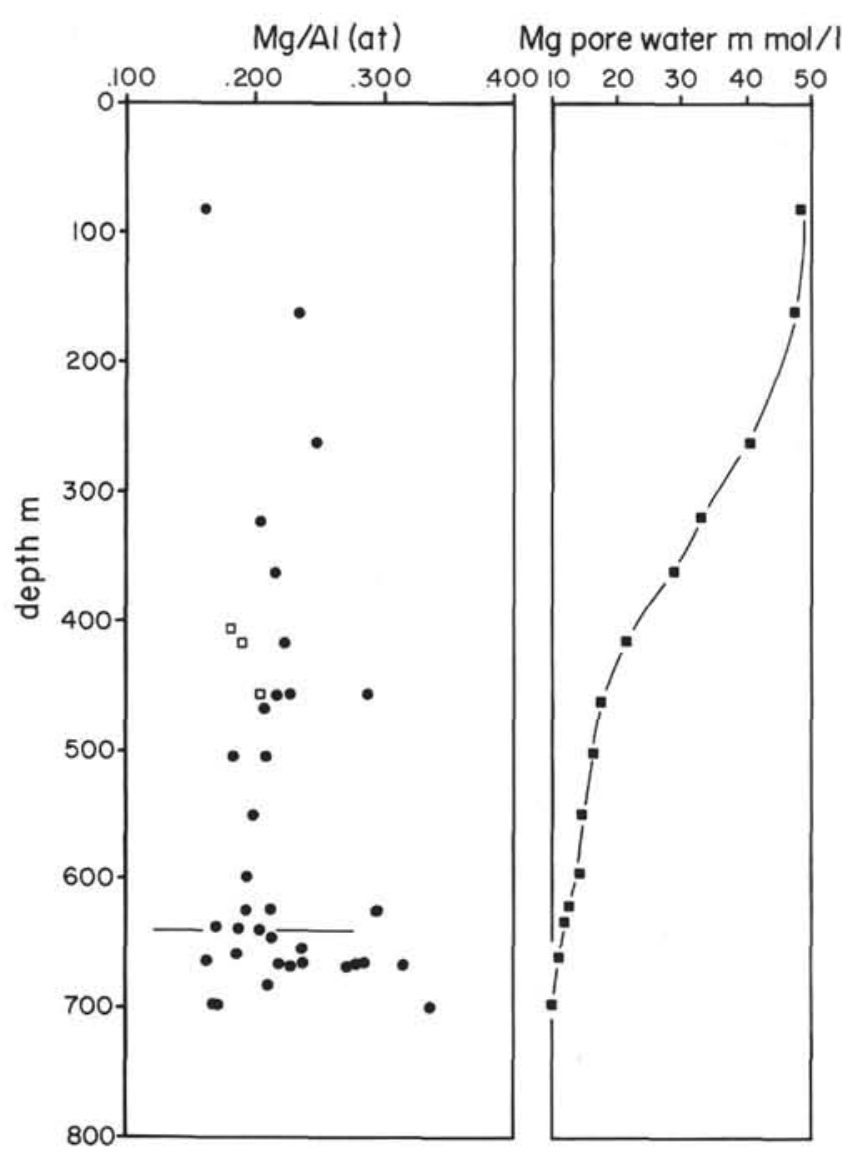

Figure 2. Graph showing $\mathrm{Mg} / \mathrm{Al}$ (atomic) and $\mathrm{Mg}$ (pore water) versus depth for Site 323. Line shows mineralogical change at 638 meters. Open squares represent chert samples.

elements ( $\mathrm{P}, \mathrm{Y}$, and possibly $\mathrm{Sr})$ occurs in this interval. However, the coherence among these elements is not strong (Figures 7,8 ), suggesting either variations in the enrichment process or some secondary redistribution of these elements.

The enrichment at Site 323 could be explained by the following scheme: hydrothermally mobilized $\mathrm{Fe}$ was transported upward from the basalt layer into the sediment where it accumulated as an oxidized iron hydrate sponge. Other elements were adsorbed on the iron hydrate sponge from seawater. A hiatus in sedimentation at the top of the 63-meter interval enabled an especially high degree of enrichment to occur in the upper part of the section; the resumption of sedimentation then occurred after hydrothermal transport of iron ceased, leaving a sharp upper boundary.

The high $\mathrm{Ba}$ content and lower $\mathrm{Rb}$ content immediately above the base of the section, and the higher $\mathrm{Sr}$ content in the lower 63 meters of Hole 323 might require a more elaborate explanation and will not be discussed here.

\section{Pore Water versus Sediment Chemistry for Site $\mathbf{3 2 3}$}

The distribution of pore-water $\mathrm{Mg}$ values (Gieskes and Lawrence, this volume; Figure 2) is not reflected in sediment chemistry. Higher $\mathrm{Si} / \mathrm{Al}$ values in the sediment are roughly correlated with higher values of pore-water Si (Figure 9), suggesting that the presence of opaline skeletal material is probably responsible for higher porewater $\mathrm{Si}$. The pore-water $\mathrm{K}$ depletion is similarly not reflected in the sediment chemistry, but probably related to the formation of authigenic $\mathrm{K}$ feldspar and/or clinoptilolite. However, this transformation is, for the most part, isochemical, as shown by the bulk compositional values.

\section{Chemistry of Coarse versus Fine-Grained Fraction}

Drever (this volume) has determined the major elements (except $\mathrm{Ti}$ ) in the coarse- and fine-grained fraction from sediments of Site 323. His results show that, in the upper part of the site, the fine-grained fraction is depleted and the coarse fraction is enriched in $\mathrm{Ca}$ and $\mathrm{Na}$ relative to the bulk sample. This confirms the supposition that these elements are in detrital plagioclase. The fine fraction is relatively enriched in $\mathrm{Mg}$ (clay) and $\mathrm{Fe}$ (iron hydrate). Below 638 meters the $\mathrm{Na}$ is fractionated more into the fine fraction and the $\mathrm{Ca}$ is approximately the same in the coarse and fine fraction, suggesting a diminishing importance of plagioclase downward. The $\mathrm{K}$ is strongly fractionated into the coarse fraction in the lower part of the interval, reflecting the growth of $\mathrm{K}$-feldspar and clinoptilolite.

\section{Summary of Site 323}

Bulk chemical compositions for major and some minor elements show a striking uniformity throughout the site. The chemical character of the sediments rules out the possibility of a basaltic source for the lower part of the hole and suggests that an island-arc volcanic origin is also improbable. The bulk composition, however, sheds no light on the reason for the putative transformation of a terrigenous sedimentary material into bentonitic montmorillonite. A possible explanation is that the process of iron enrichment included some mild hydrothermal alterations as well as hydrothermal transport. However, the range of geological experience does not encompass examples showing us what might happen to a very fine-grained aggregate of terrigenous clay minerals held at low pressure in seawater for several tens of millions of years. Certainly its transformation into a bentonitic clay, as does volcanic glass under the same circumstances, cannot be easily ruled out. The character of lower Site 323 sediments suggests that much Paleogene and Cretaceous deep-sea bentonitic montmorillonite might also be transformed terrigenous clay suites.

\section{SITE 322}

\section{Upper Part}

The chemistry of Site 322 sediments is very similar to that of Site 323, with, however, a more limited zone of iron enrichment. The upper part (down to $438 \mathrm{~m}$-the principal mineralogical break of Perry et al., this volume) is again a terrigenous suite with chemical ratios similar to those of Site 323 and other pelagic sites (Table 4). The $\mathrm{K} / \mathrm{Al}$ (Figure 10) ratio is lower (hence, more "normal"), reflecting a lower illite contenz. The $\mathrm{Si} / \mathrm{Al}$ ratio (Figure 10) is somewhat high, as is typical of other 

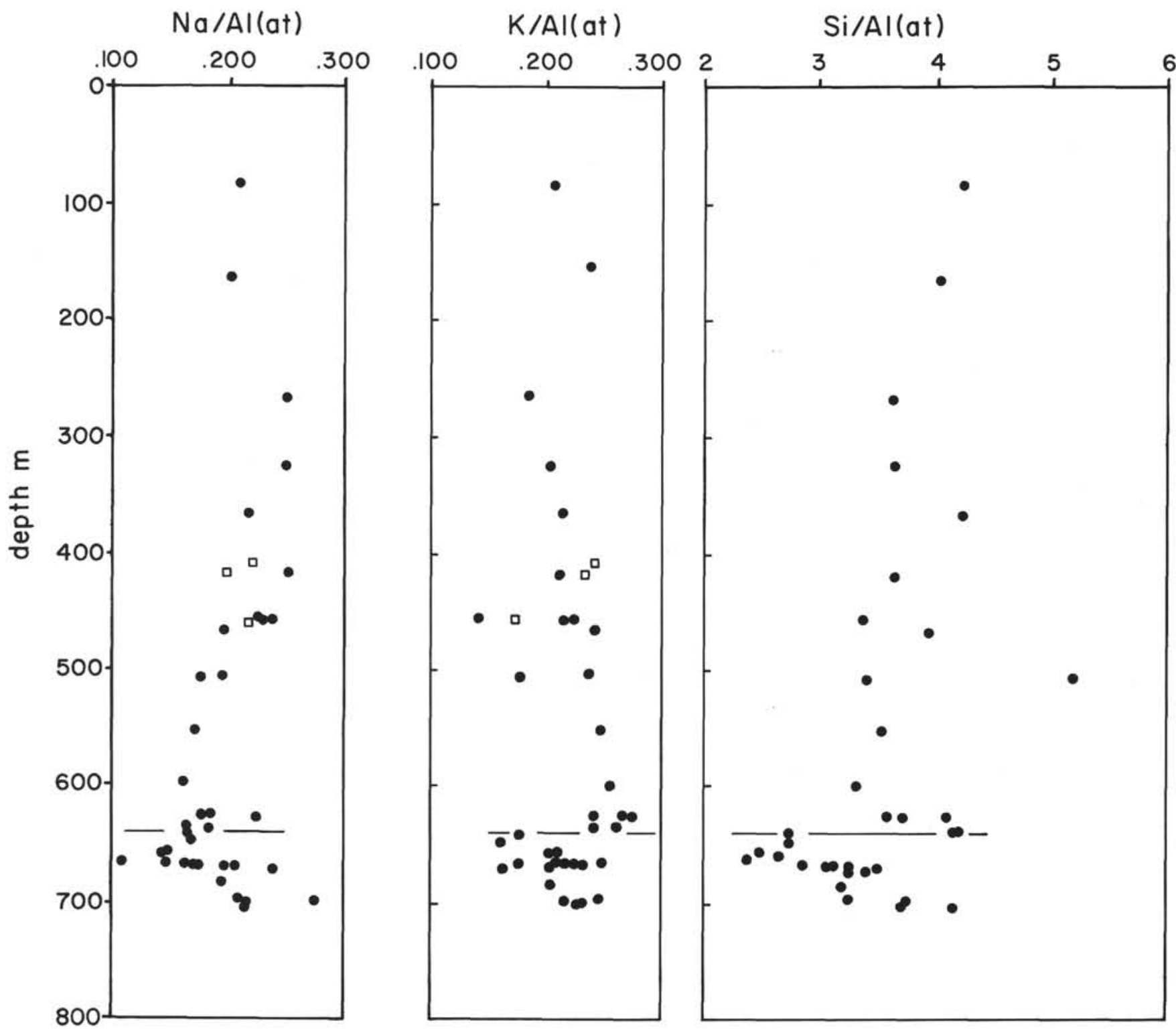

Figure 3. Graph showing $\mathrm{Na} / \mathrm{Al}, \mathrm{K} / \mathrm{Al}$, and $\mathrm{Si} / \mathrm{Al}$ (atomic) versus depth for Site 323. Line shows mineralogical change at 638 meters.

Pacific sites and, together with $\mathrm{Fe} / \mathrm{Al}$ (Figure 11), increases upwards, suggesting parallel explanations for Sites 322 and $323 . \mathrm{Ca}$ is somewhat higher at this site than at Site 323, which, along with higher plagioclase/ quartz content (Zemmels and Cook, this volume) suggests a higher plagioclase content than at Site 323 .

\section{Middle Part}

The bulk chemistry of middle portion of the Site 322 sediments is similar to that of the upper part, as was the case for Site 323. Critical elemental ratios (Table 4) show that, except for higher $\mathrm{Si} / \mathrm{Al}$ and $\mathrm{Fe} / \mathrm{Al}$ in the upper part (analogous to the variation throughout the upper part of Site 323), there is near chemical identity. Thus, the conclusion of Perry et al. (this volume) that the material below 438 meters is dominantly volcanic (type of volcanism unspecified) would require it to compositionally closely mimic the upper, clearly terrigenous, sediment. A more likely explanation is that this material is mineralogically transformed older terrigenous detritus.

\section{Lower Part}

The lower 4 meters of Site 322 shows Fe enrichment analogous to that at Site 323 and other localities cited above. The remainder of the critical chemical ratios is similar to the upper part and to terrigenous sediment in general, indicating again that the bulk of this sediment is ronvolcanic. However, the $\mathrm{K} / \mathrm{Al}$ ratio is much higher here, corresponding with occurrences of mica (type unspecified). Perry et al. describe this mica as detrital illite.

A correlation between $\mathrm{Fe} / \mathrm{Al}$ and $\mathrm{K} / \mathrm{K}+\mathrm{Na}$ for Site 322 is shown in Figure 12. The correlation may be fortuitous, or it might reflect an unrecognized phenomenon. If the relationship exists, unfortunately it is unclear which variable is dependent and which independ- 


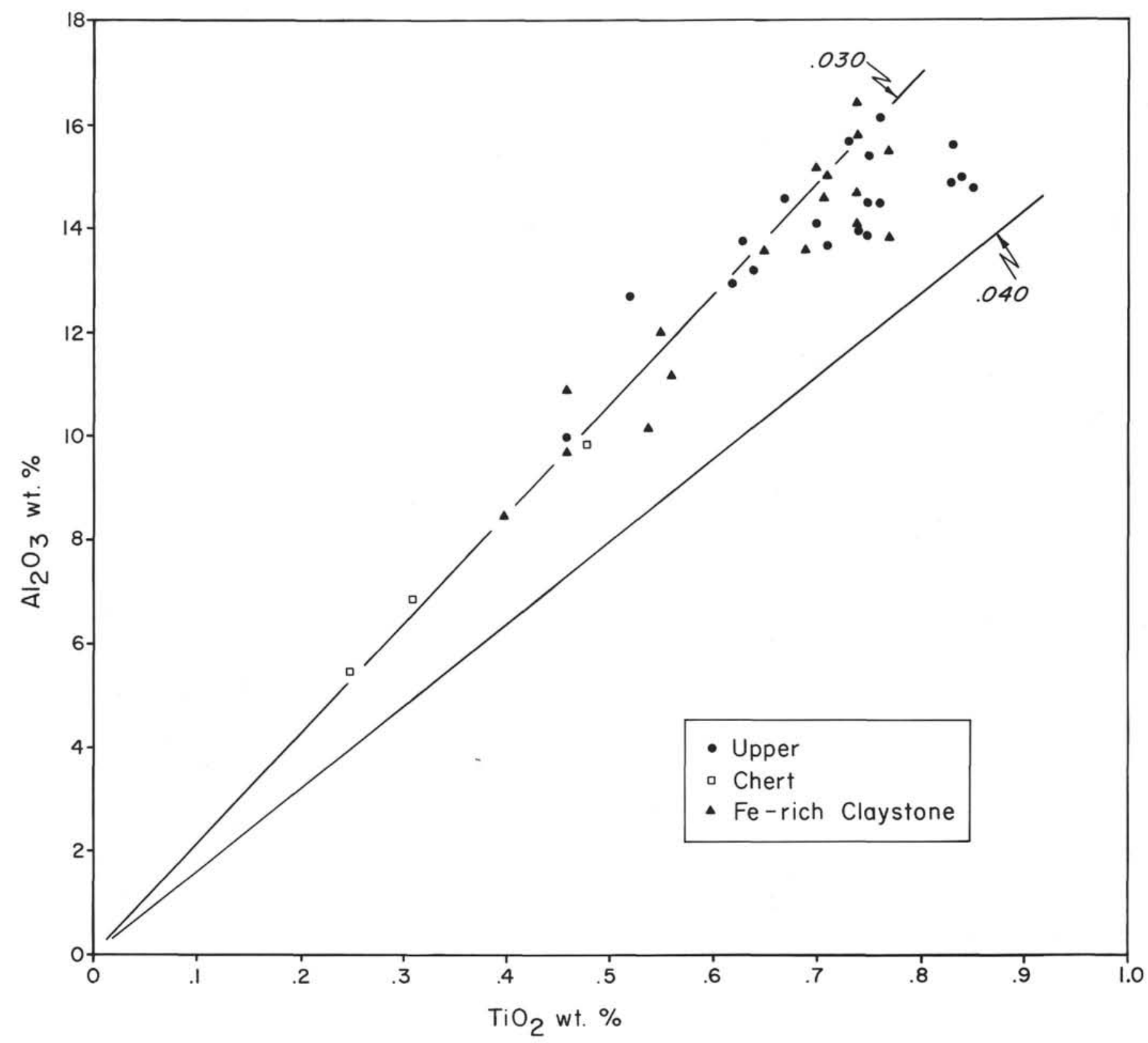

Figure 4. Graph showing $\mathrm{TiO}_{2}$ versus $\mathrm{Al}_{2} \mathrm{O}_{3}$ for Site 323. Fe-rich claystone refers to samples deeper than 638 meters. Lines show values for Ti/Al (atomic).

ent. The data of Perry et al. (this volume) show that the $\mathrm{K} / \mathrm{Al}$ ratios of the coarse and fine fractions are similar in this interval, showing that $\mathrm{K}$ is not preferentially distributed in either a coarse or fine mineral. It is possible that the basal mica could be secondary although our experience with other pelagic clay sections shows that $\mathrm{K}$ is a conservative element, generally being enriched only in palagonites and some zeolitic clays.

The iron enrichment of basal Site 322 is parallel to that of 323 (Figures 13, 8), Mn and $\mathrm{P}$ are also enriched, but are presently not completely coherent. Two samples (Table 3) were analyzed for minor elements; $\mathrm{Zr}$ was much the same, $\mathrm{Rb}$ and $\mathrm{Ba}$ higher, and $\mathrm{Sr}$ somewhat lower than in the unenriched sediment.

\section{Pore Water of Site 322}

Pore-water results for Site 322 (Gieskes and Lawrence, this volume) were parallel to those for Site
323 , but with less dramatic depletion of $\mathrm{Mg}$ and $\mathrm{K}$. The relationship between the sediment $\mathrm{Si} / \mathrm{Al}$ ratio and porewater Si (Figure 14) again shows the effect of biogenic opal. The depletion of $\mathrm{Mg}$ in the pore water is not reflected by a noticeable rise in $\mathrm{Mg} / \mathrm{Al}$ in the sediment (Figure 15); evidently $\mathrm{Mg}$ has been (or is still being) consumed in the mineral transformation of the middle part of the sequence. K depletion near the base of Hole 322 might be attributable to K uptake in the sediments, or to alteration of the basalt.

\section{Summary of Site 322}

On the basis of general chemical similarity, near identity of $\mathrm{Ti}$ and $\mathrm{Al}$ (Figure 16), and minor elements (Table 3 ), we conclude that Site 322 is analogous to Site 323: the material is dominantly terrigenous throughout, with only a trivial amount of admixed volcanic debris. We have no explanation for the high $\mathrm{K} / \mathrm{Al}$ in the lower 4 


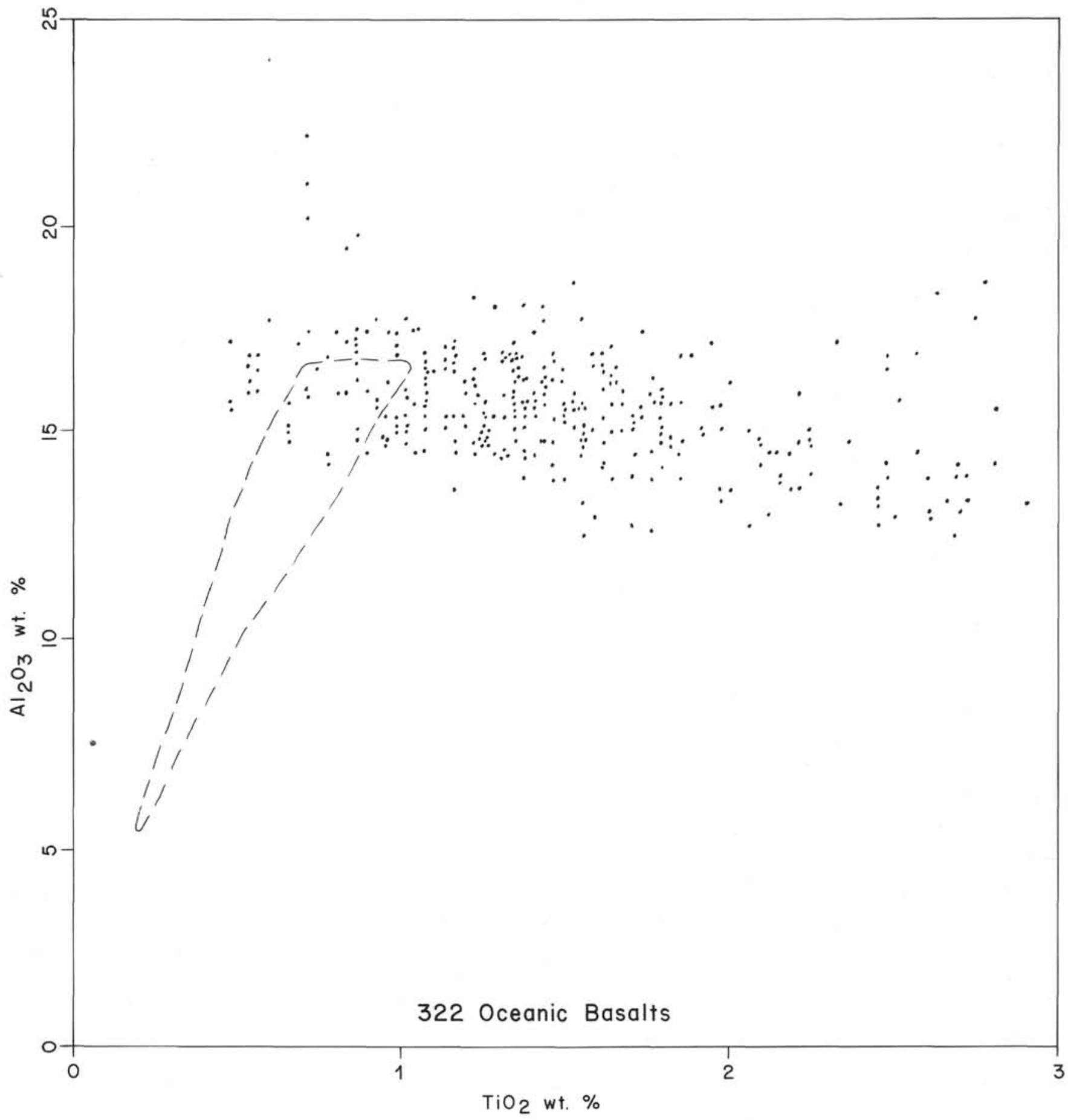

Figure 5. Graph showing $\mathrm{TiO}_{2}$ versus $\mathrm{Al}_{2} \mathrm{O}_{3}$ for 322 drilled and dredged oceanic basalts, taken from various volumes of the Initial Reports of the Deep Sea Drilling Project, and other sources. The envelope of 72 analyses of Leg 35 sediments is shown as a dashed line.

meters, but feel it is not critical to either argument. This site again raises the question as to whether a finegrained pelagic suite of clay minerals of terrigenous origin can transform to a mixture of bentonitic montmorillonite and other authigenic minerals. In the case of Site 322, however, the top of the iron-enriched zone does not coincide with the top of the bentonitic montmorillonite; this would tend to limit the probability that hydrothermal alteration accompanying secondary up- ward iron transport might be responsible for the overall mineral transformation.

SITE 325

Site 325 is chemically very similar to the other two sites in all critical parameters (Table 4, Figures 17, 18, 19,20 ). The $\mathrm{K} / \mathrm{Al}$ ratio is similar to those of the upper and middle parts of Site 322 . 


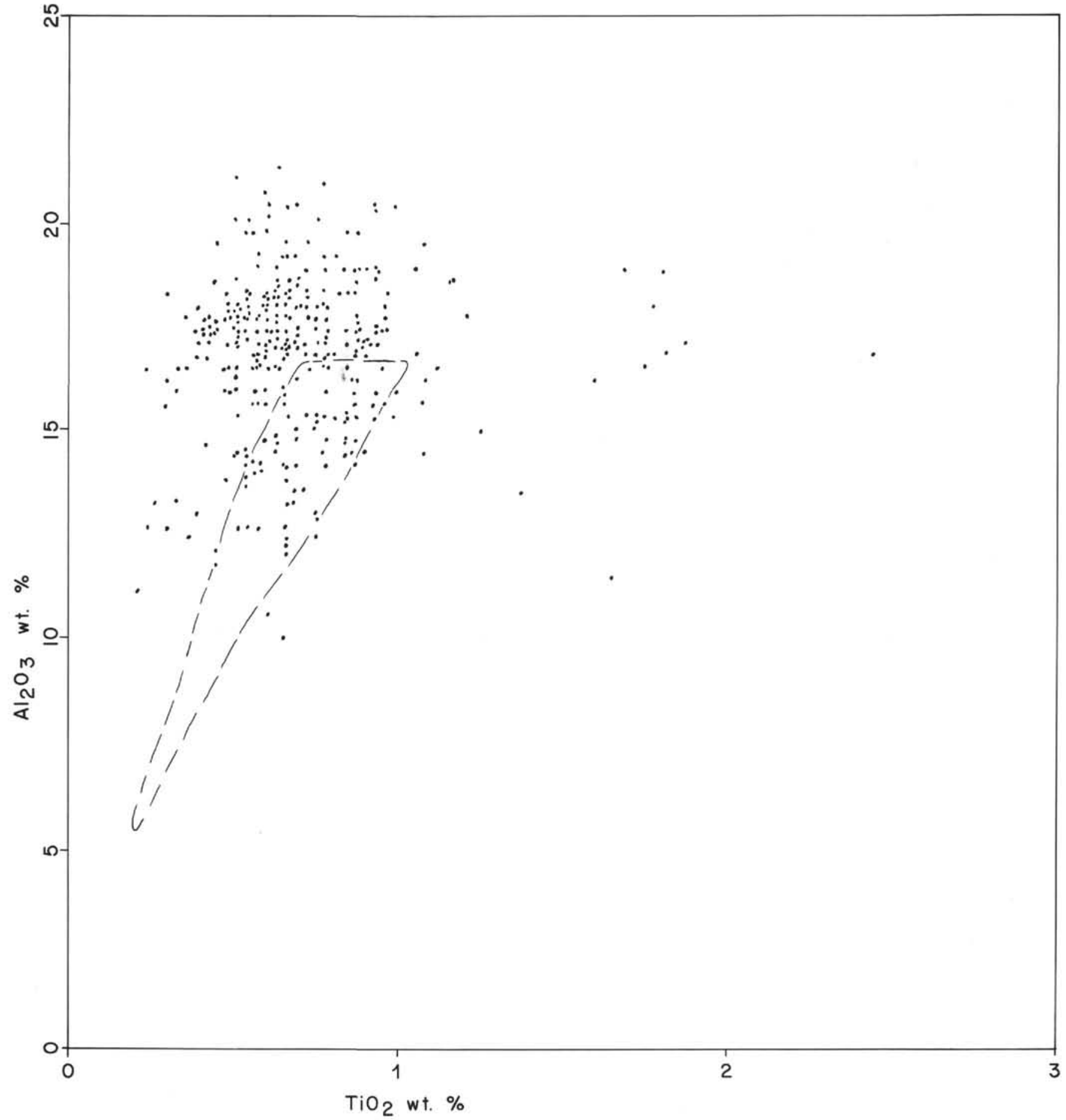

Figure 6. Graph showing $\mathrm{TiO}_{2}$ versus $\mathrm{Al}_{2} \mathrm{O}_{3}$ for 319 calcalkaline volcanic rocks from the Caribbean and Pacific. Compiled from unpublished analyses and numerous published sources. The envelope of 72 Leg 35 sediments is shown, as in Figure 5. It should be noted that pyroclastic examples tend to cluster to the left (low-Ti) side, and lavas to the right.

Pore-water studies of Site 325 (Gieskes and Lawrence, this volume) show very strong depletions of $\mathrm{K}$ and $\mathrm{Mg}$ in the lower part of the section. Although the $\mathrm{Mg} / \mathrm{Al}$ ratio is slightly higher in the lower Site 325 sediments (Figure 20), the relationship between $\mathrm{Mg} / \mathrm{Al}$ ratio and pore-water $\mathrm{Mg}$ is unclear. The ratio between $\mathrm{Mg}$ in sediment and $\mathrm{Mg}$ in pore water is approximately 10 to 1 ; therefore, complete exhaustion of pore-water $\mathrm{Mg}$ results in little increase of the $\mathrm{Mg} / \mathrm{Al}$ ratio in the sediment.

\section{ALTERATION OF BASALTS FROM SITES 322 AND 323}

Six chemical analyses of apparently altered basalts from Sites 322 and 323 are compared in Table 2. The 


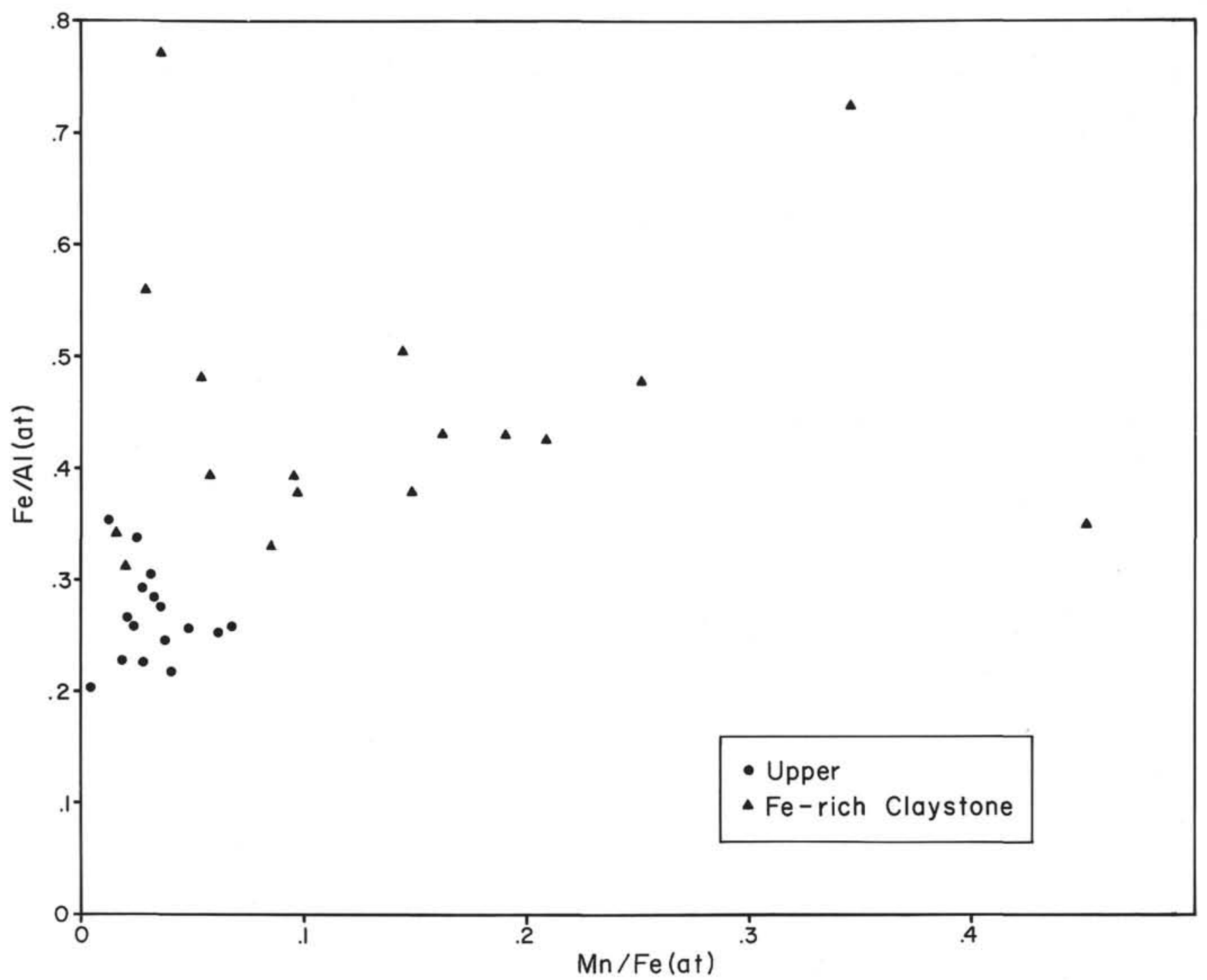

Figure 7. Graph showing $\mathrm{Fe} / \mathrm{Al}$ (atomic) versus $\mathrm{Mn} / \mathrm{Fe}$ (atomic) for Site 323. Symbols as in Figure 4.

small size of the samples precluded water determinations; thus, the $\mathrm{Fe}^{+3} / \mathrm{Fe}^{+2}+\mathrm{Fe}^{+3}$ ratio will have to serve as the sole index of alteration. (Interestingly, samples selected visually for maximum and minimum degrees of alteration were found to be very similar, even in the ferric iron ratio!) The data of Table 2, which include supposedly fresher basalts from the same sites analyzed by J. Norberg of the Smithsonian Institution, show that in both sites $\mathrm{MgO}$ decreases slightly with increasing apparent alteration. Thus, weathered basalt would not appear to be a sink for $\mathrm{Mg}$ ions in the pore water. $\mathrm{Ca}$ appears to decrease slightly with alteration, and, on the basis of these data, the basalts could be a possible source for pore-water Ca. The behavior of $\mathrm{K}$ is more problematical. Its abundance is generally high (as compared to MORB) and most likely has been enriched during weathering. However, it is perversely and inversely correlated with the ferric iron ratio at Site 322 and Core 323-18. The behavior of $\mathrm{K}$ is further complicated in that the Site 323 basalts show $\mathrm{Ti}$ values and $\mathrm{Fe} / \mathrm{Mg}$ ratios which are less typical of MORB than of more fractionated basalts from oceanic islands and other elevated oceanic areas. Thus, the original $\mathrm{K}$ content of Site 323 is not known, though it was probably less than what is now present, especially in Core 323-18. The higher value of $\mathrm{Cl}$ in Core 323-18 supports the supposition of a higher degree of alteration in these samples.

\section{SUMMARY}

The major-element chemistry of Sites 322, 323, and 325 reflects dominantly continentally derived detritus with minimal secondary modifications (Figure 21). Primary variations in detrital plagioclase, in the amount of opaline debris, and in the $\mathrm{Fe} / \mathrm{Al}$ ratio of the detritus appear to be responsible for some of the minor chemical variations. Secondary additions of $\mathrm{K}$ or $\mathrm{Mg}$ possibly occurred in some sediments. The evidence is not completely convincing, but there is some correlation with observed pore-water depletions of these elements.

The enrichment of iron, manganese, and phosphorus in basal Sites 322 and 323 sediments is inferred to have 


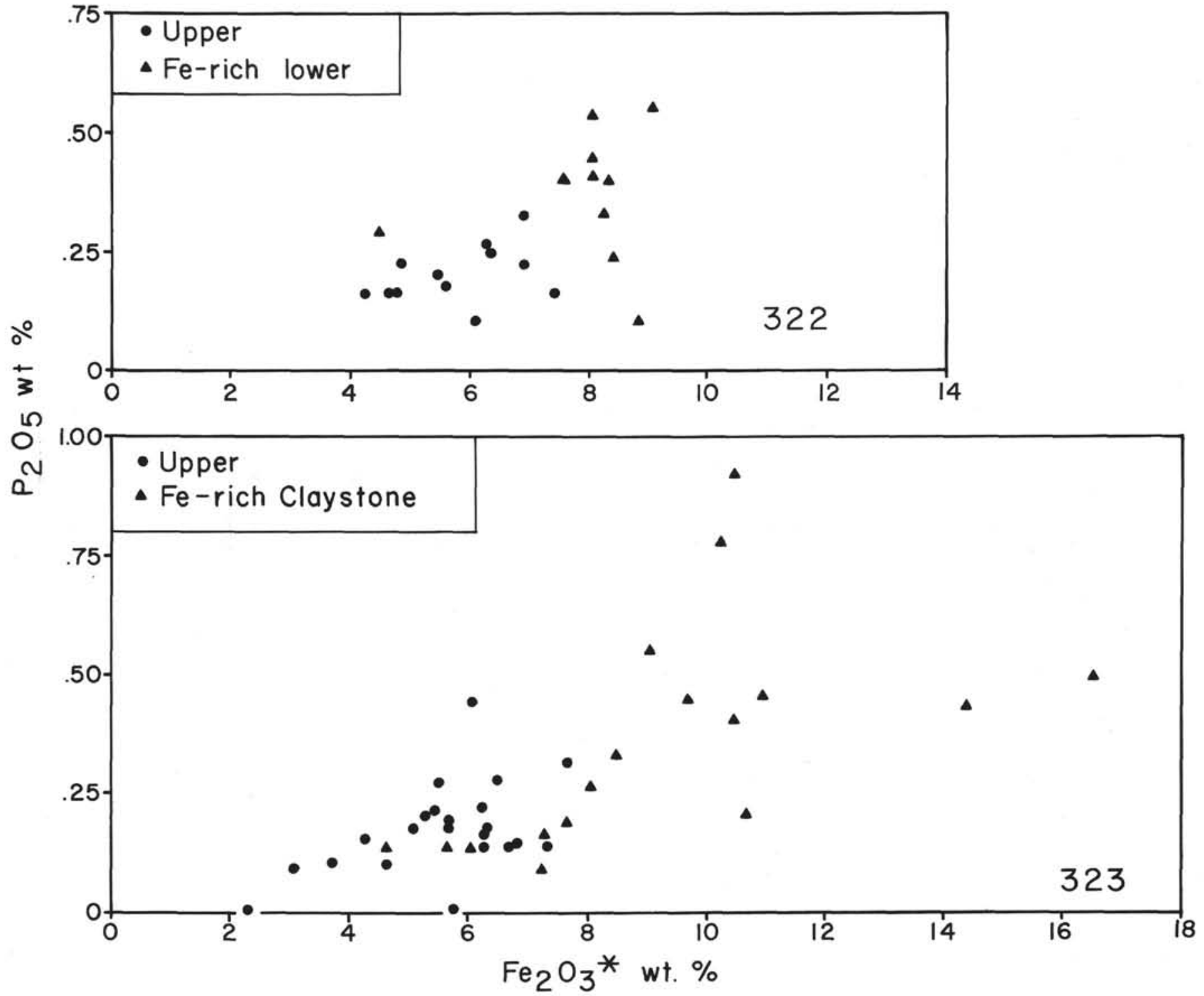

Figure 8. Graph showing $\mathrm{P}_{2} \mathrm{O}_{5}$ versus $\mathrm{Fe}_{2} \mathrm{O}_{3}$ for Sites 322 and 323. Symbols as in Figures 4 and 16.

been caused by accumulation of hydrothermally mobilized iron which oxidized at the sediment-water interface to form a hydrated iron-oxide sponge, which in turn adsorbed $\mathrm{Mn}$ and $\mathrm{P}$. Although the significance of the correlation between the change in $\mathrm{Fe}, \mathrm{Mn}$, and $\mathrm{P}$ and the mineralogy (appearance of secondary, bentonitic mineralogy) at Site 323 is uncertain, the general chemical similarity across this boundary supports an hypothesis of original mineralogical similarity and subsequent mineralogical change in the iron-enriched zone. This change was possibly catalyzed by the presence of the iron or caused by the hydrothermal process in which iron was transported.

The principal contribution of the major-element chemistry at these sites to understanding secondary mineral formation is to emphasize the essentially isochemical nature of the transitions. Pore-water depletion of $\mathrm{Mg}$ and $\mathrm{K}$ are only partly reflected in sediment chemistry and there is no convincing explanation based on the chemistry of the sediments for $\mathrm{Ca}$ enrichment in the pore water.

\section{ACKNOWLEDGMENTS}

This study was supported by NSF Grant AO 43210. Sediment samples were made available by the National Science Foundation. We are grateful to Beth Carroll for the instrumental portion of the minor element analyses.

\section{REFERENCES}

Boström, K., 1973. The origin and fate of ferromanganoan active ridge sediments: Stockholm Contrib. Geol., v. 27, p. 148-243.

Boström, K. and Peterson, M.N.A., 1966. Precipitates from hydrothermal exhalations of the East Pacific Rise: Econ. Geol., v. 61, p. 1258-1265.

Boström, K., Joensuu, O., Valdes, S., and Riera, M., 1972. Geochemical history of South Atlantic Ocean sediments since Late Cretaceous: Marine Geol. v. 2, p. 25-121.

Bowles, F.A., Jack, R.N., and Carmichael, I.S.E., 1973. Investigation of deep-sea volcanic ash layers from equatorial Pacific cores: Geol. Soc. Am. Bull., v. 84, p. 2371-2388.

Donnelly, T.W. and Nalli, G., 1973. Mineralogy and chemistry of Caribbean sediments. In Edgar, N.T., 


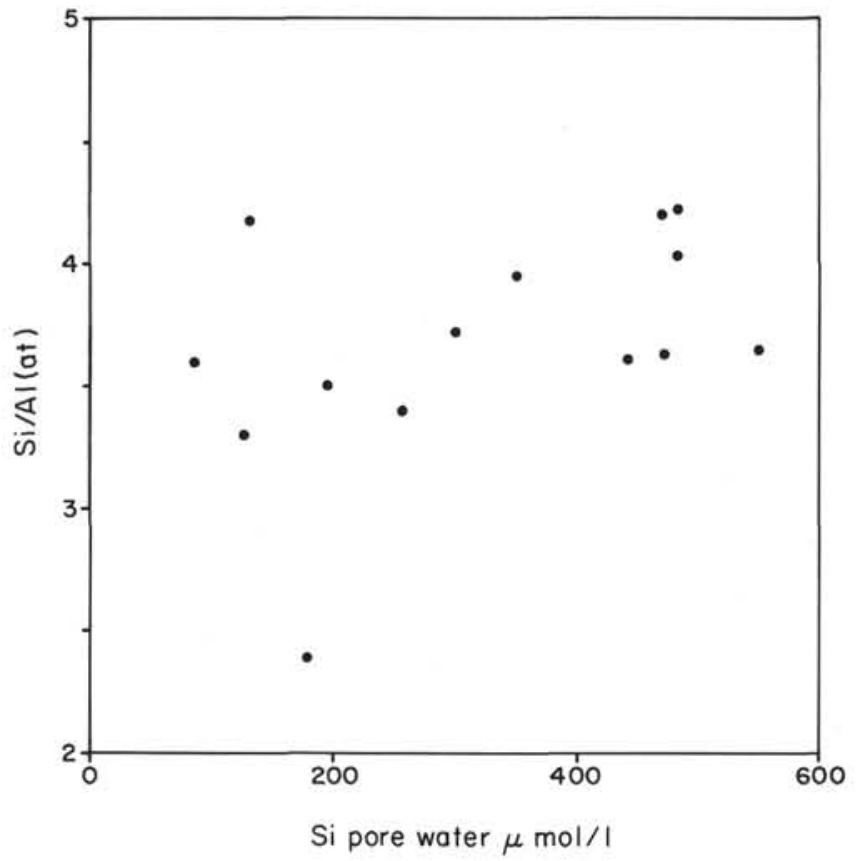

Figure 9. Graph showing Si/Al (atomic) versus Si (pore water) for Site 323.

Saunders, J.B., et al., Initial Reports of the Deep Sea Drilling Project, Volume 15: Washington (U.S. Government Printing Office), p. 929-961.

Donnelly, T.W. and Wallace, J.L., 1976. Major-element chemistry of the Tertiary of Site 317 and the problem of the origin of the non-biogenic fraction of pelagic sediments. In Jackson, E.D., Schlanger, S.O., et al., Initial Reports of the Deep Sea Drilling Project, Volume 33: Washington (U.S. Government Printing Office), p. 557-562.

Hart, R., 1970. Chemical exchange between sea water and deep ocean basalts: Earth Planet. Sci. Lett., v. 9, p. 269-279.

Hower, J., 1959. Matrix corrections in X-ray spectrographic trace element analysis: Am. Mineral., v. 44, p. 19-32.

McKelvey, B.C. and Fleet, A.J., 1974. Eocene basaltic pyroclastics at Site 253, Ninetyeast Ridge. In Davies, T.A., Luyendyk, B.P., et al., Initial Reports of the Deep Sea Drilling Project, Volume 26: Washington (U.S. Government Printing Office), p. 553-565.

Melson, W.G., 1973. Basaltic glasses from the Deep Sea Drilling Project. Chemical characteristics, composition of alteration products, and fission-track "ages" (Abstract): EOS, p. 1011-1014.

Melson, W.G. and Thompson, G., 1973. Glassy abyssal basalts, Atlantic sea floor near St. Paul's Rocks: Petrography and composition of secondary clay minerals: Geol. Soc. Bull., v. 84, p. 703-716.

Pettijohn, F.J., 1957. Sedimentary rocks: New York (Harper \& Bros.).

Shaw, D.M., 1956. Geochemistry of pelitic rocks. Part III: Major elements and general geochemistry: Geol. Soc. Am. Bull., v. 67, p. 919-934.

Thompson, A., 1973. A geochemical study of the lowtemperature interaction of sea-water and oceanic igneous rocks (Abstract): EOS, p. 1015-1019.

Vinogradov, A.P. and Ronov, A.B., 1956. Composition of the sedimentary rocks of the Russian platform in relation to the history of its tectonic movements: Geochemistry, p. 533-559.
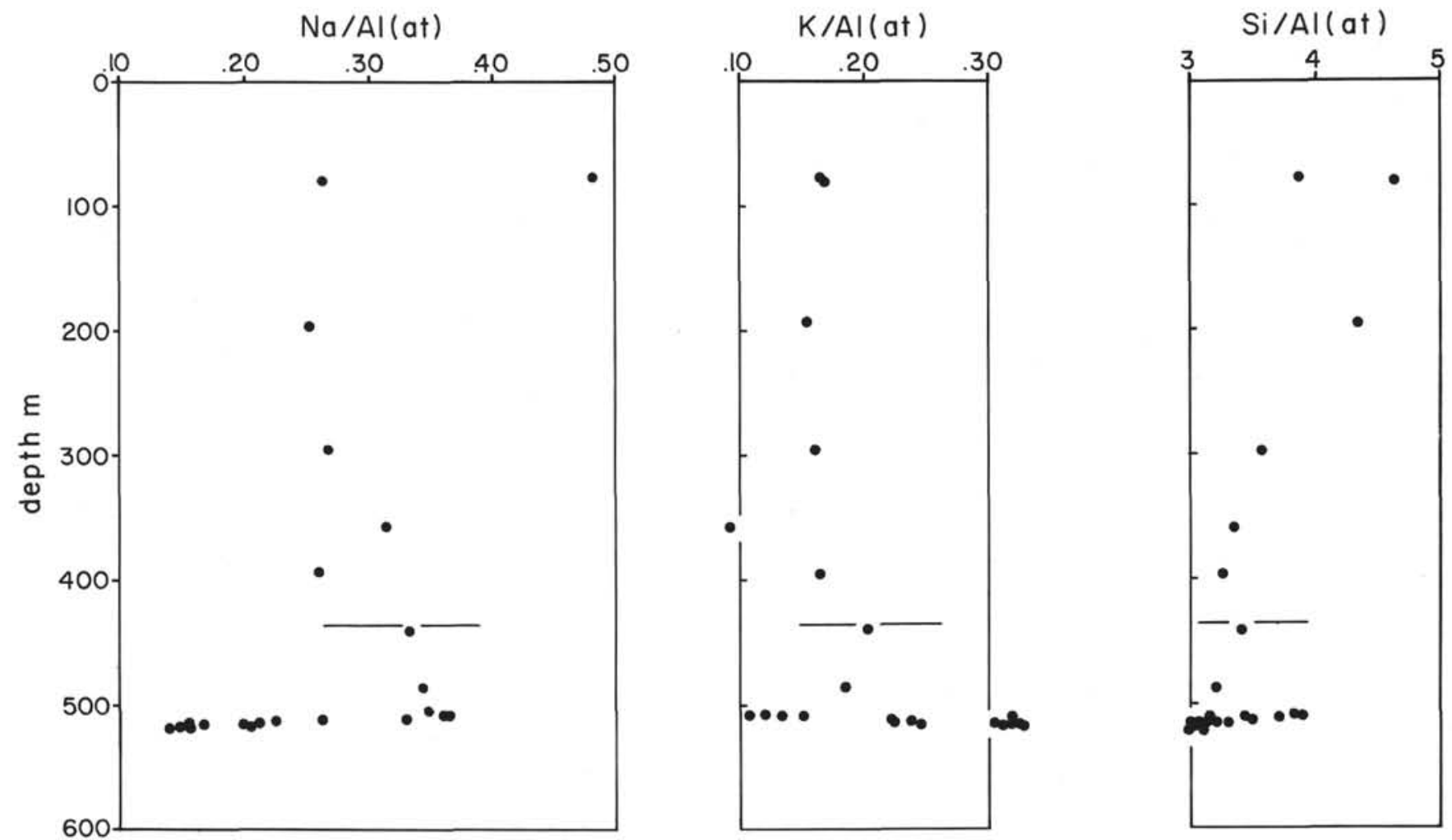

Figure 10. Graph showing $\mathrm{Na} / \mathrm{Al}, \mathrm{K} / \mathrm{Al}$, and Si/Al (atomic) versus depth for Site 322. Line shows mineralogical change at 438 meters. 


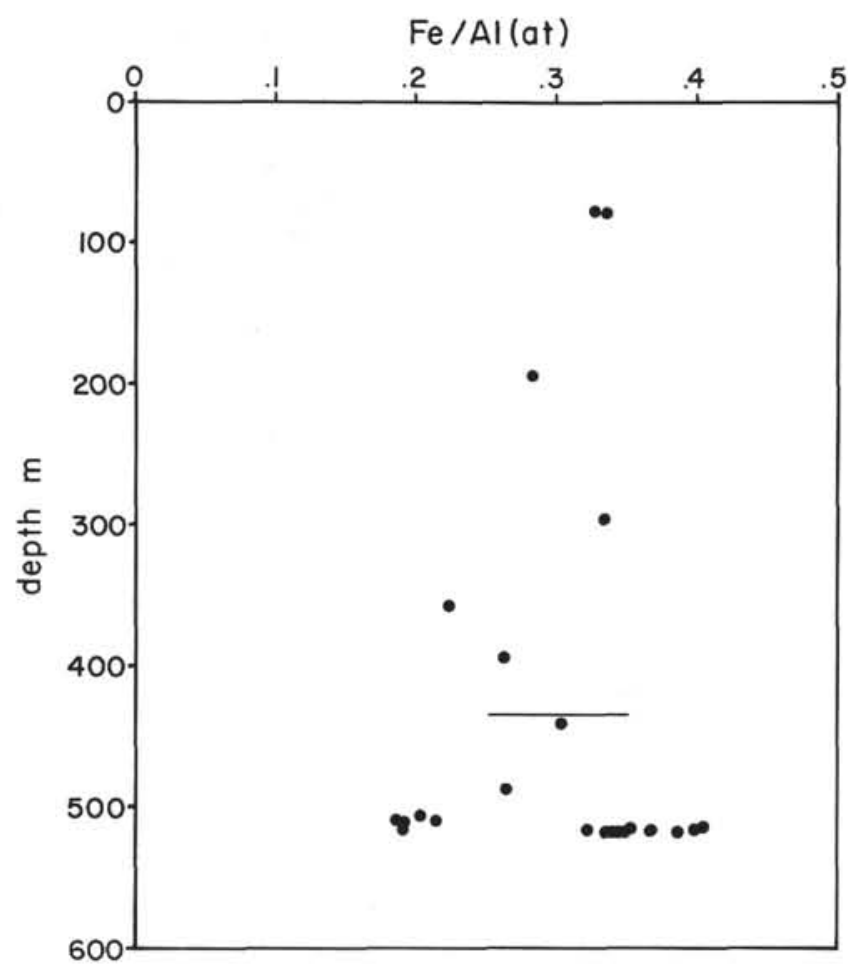

Figure 11. Graph showing $\mathrm{Fe} / \mathrm{Al}$ (atomic) versus depth for Site 322. Line shows mineralogical change at 438 meters. 


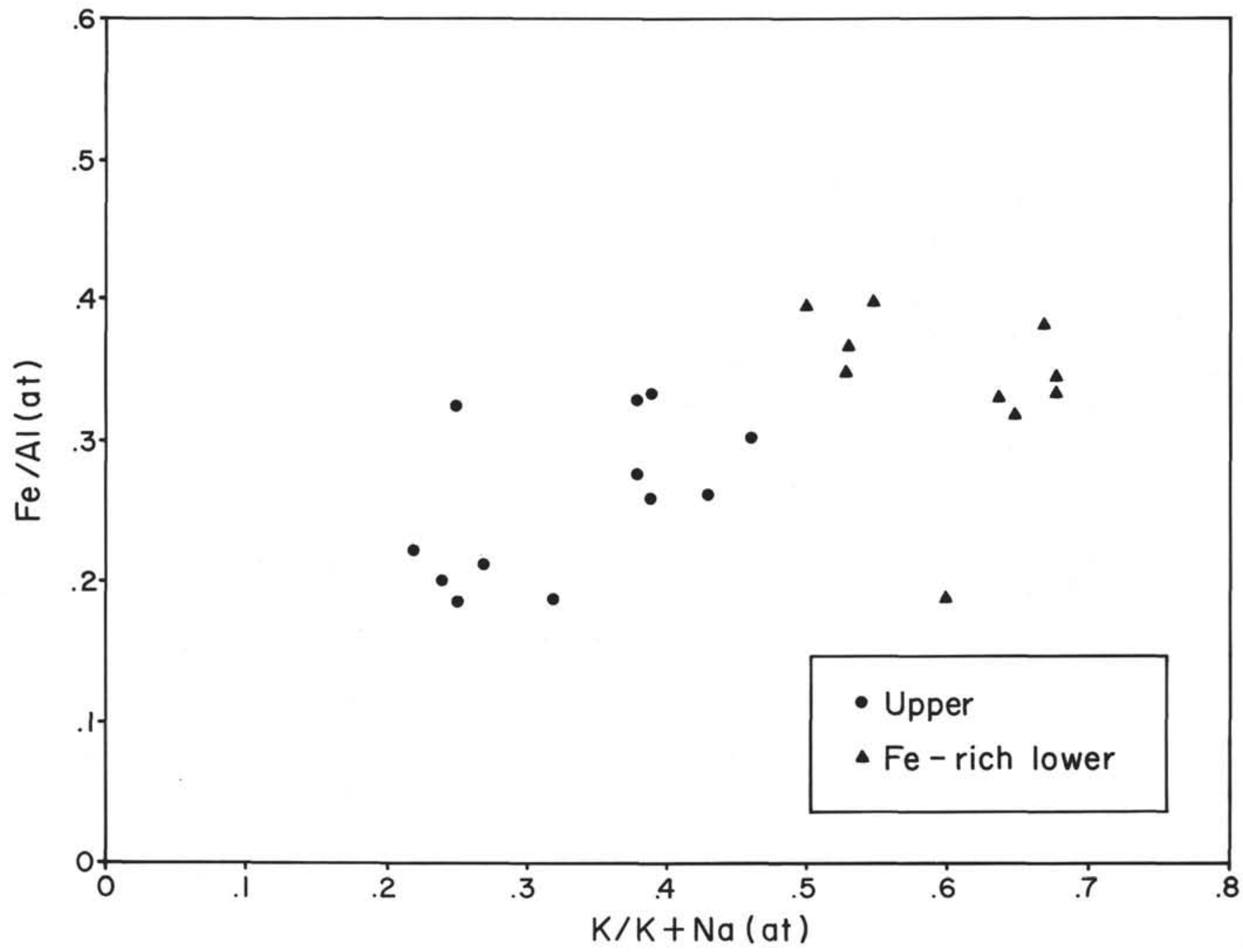

Figure 12. Graph showing $\mathrm{Fe} / \mathrm{Al}$ (atomic) versus $\mathrm{K} / \mathrm{K}+\mathrm{Na}$ (atomic) for Site 322. Symbols as in Figure 16.

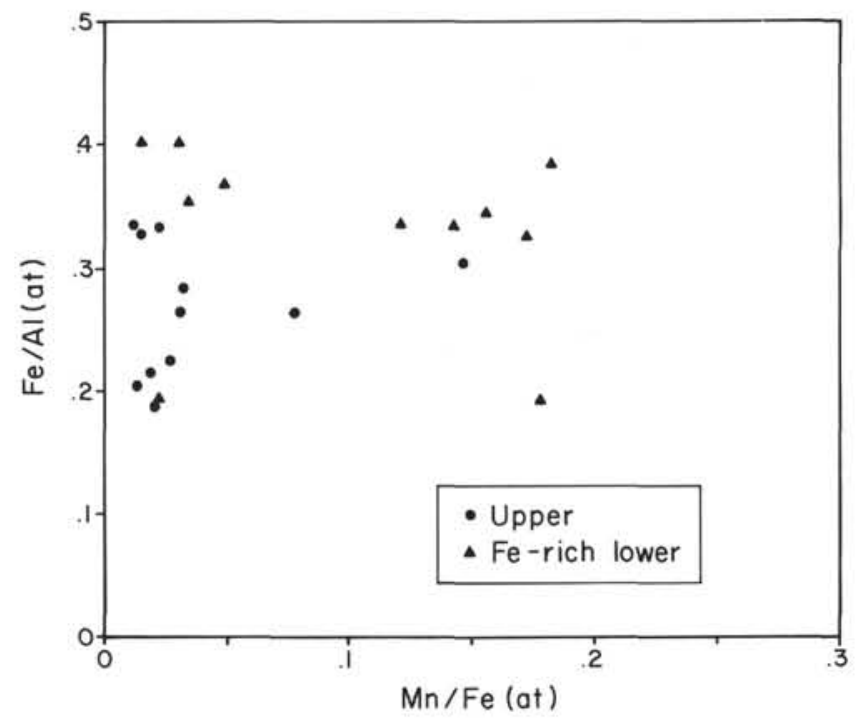

Figure 13. Graph showing $\mathrm{Fe} / \mathrm{Al}$ (atomic) versus $\mathrm{Mn} / \mathrm{Fe}$ (atomic) for Site 322. Symbols as in Figure 16. 


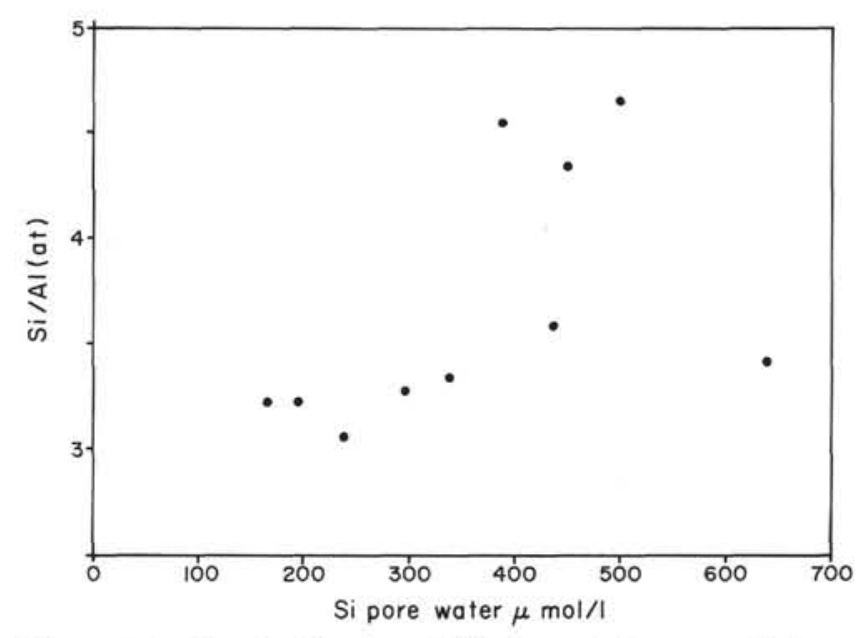

Figure 14. Graph showing Si/Al (atomic) versus Si (pore water) for Site 322.

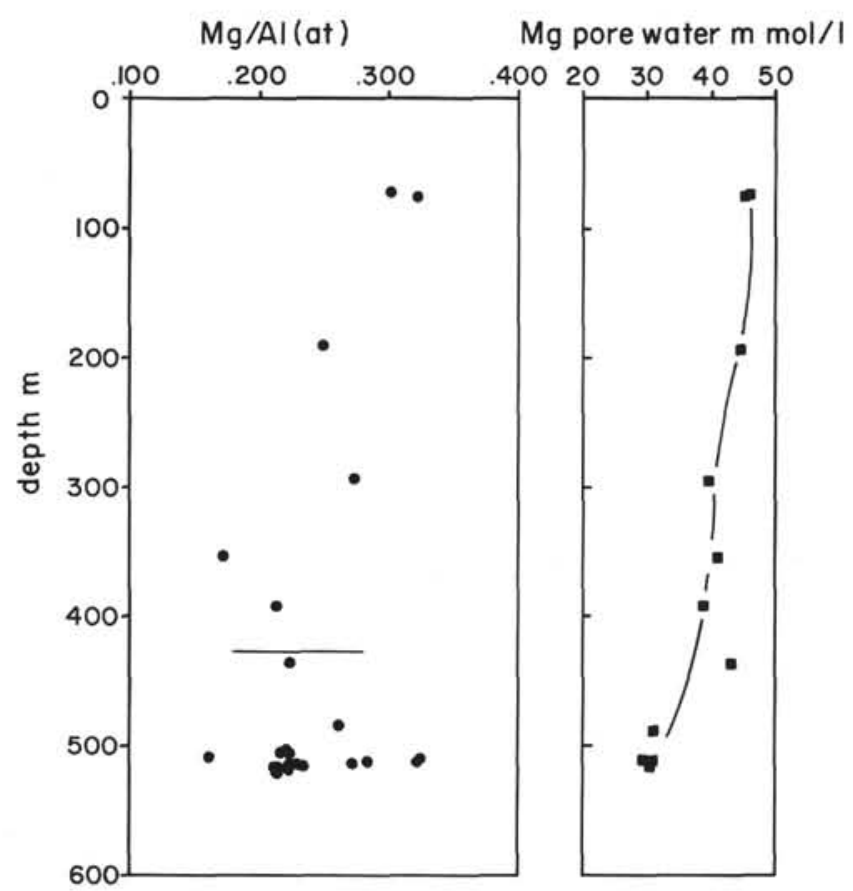

Figure 15. Graph showing $M g / A l$ (atomic) and $M g$ (pore water) versus depth for Site 322. Line shows mineralogical change at 438 meters. 


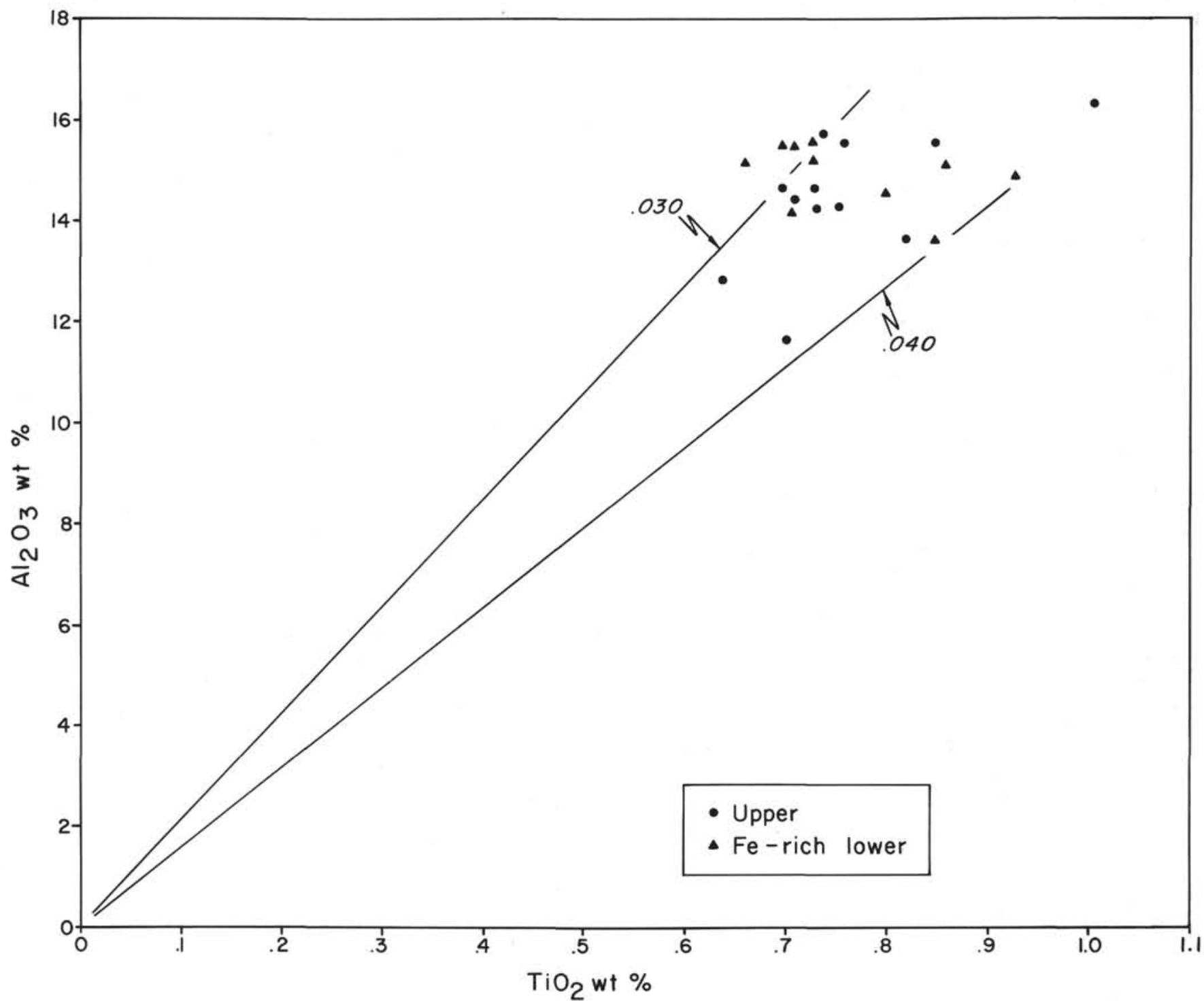

Figure 16. Graph showing $\mathrm{TiO}_{2}$ versus $\mathrm{Al}_{2} \mathrm{O}_{3}$ for Site 322. Fe-rich lower part refers to samples deeper than 510 meters. Lines show values for Ti/Al (atomic). 
T. W. DONNELLY, J. L. WALLACE

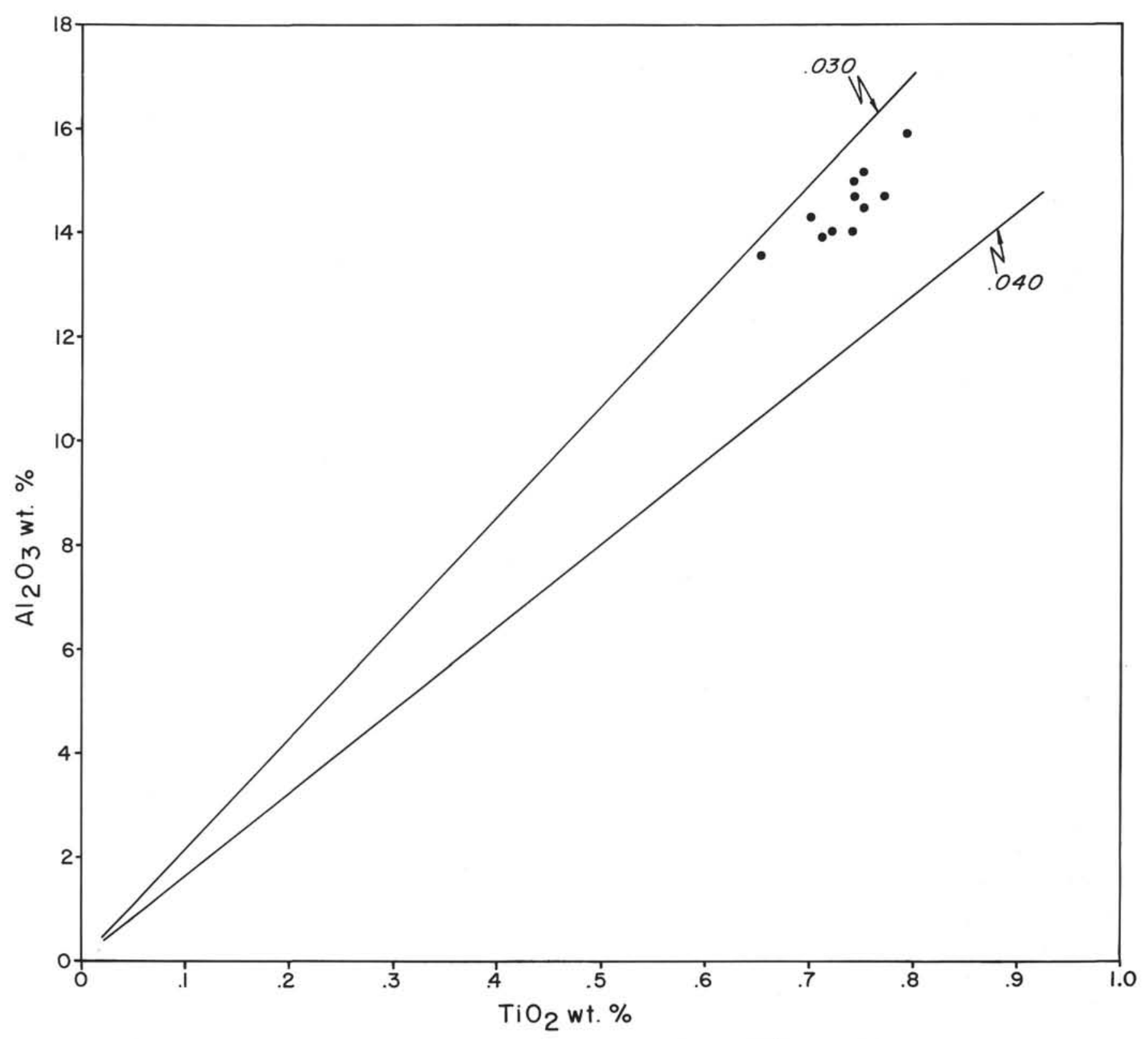

Figure 17. Graph showing $\mathrm{TiO}_{2}$ versus $\mathrm{Al}_{2} \mathrm{O}_{3}$ for Site 325. Lines show values for Ti/Al (atomic). 

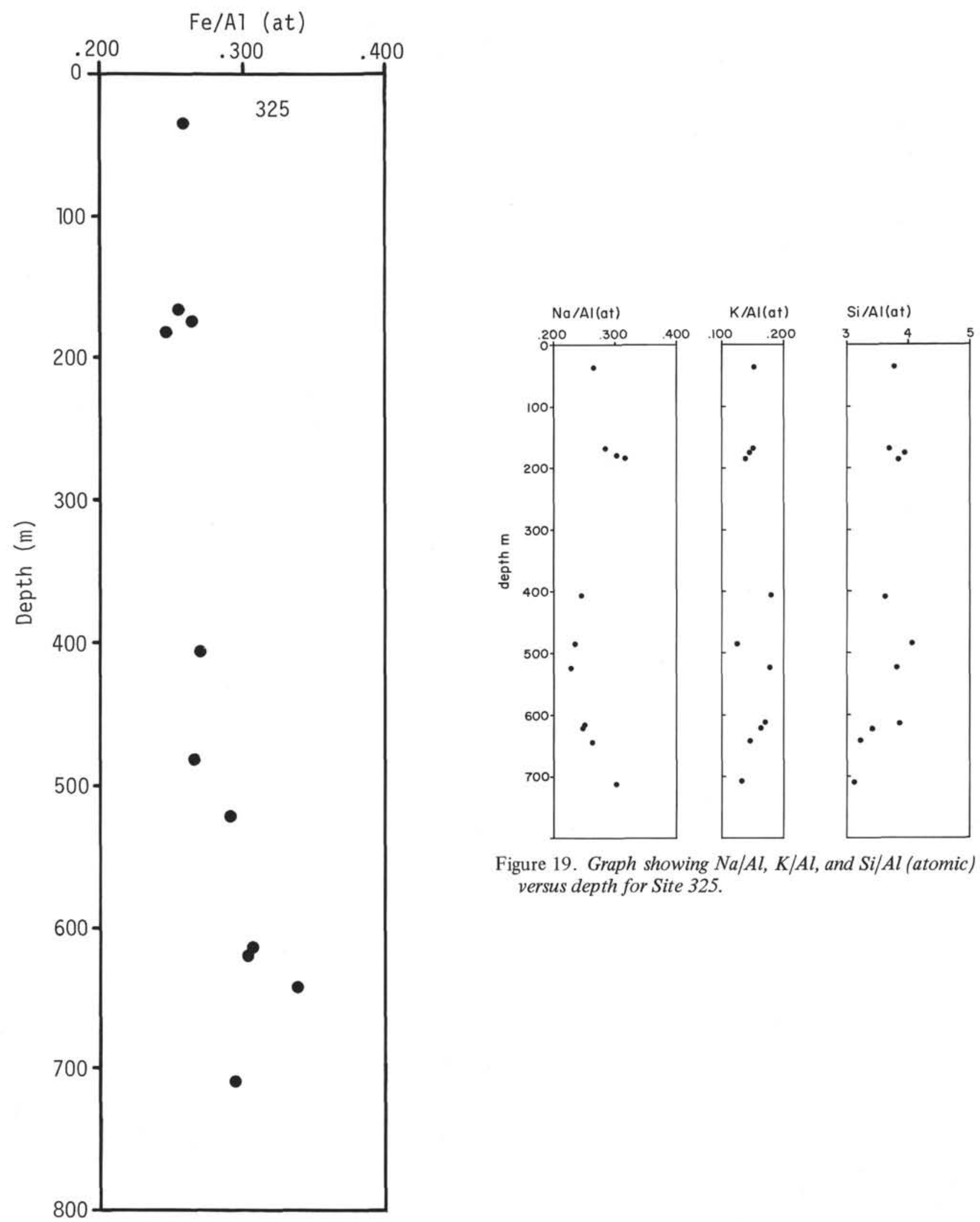

Figure 19. Graph showing $\mathrm{Na} / \mathrm{Al}, \mathrm{K} / \mathrm{Al}$, and $\mathrm{Si} / \mathrm{Al}$ (atomic) versus depth for Site 325.

Figure 18. Graph showing $\mathrm{Fe} / \mathrm{Al}$ (atomic) versus depth for Site 325 . 

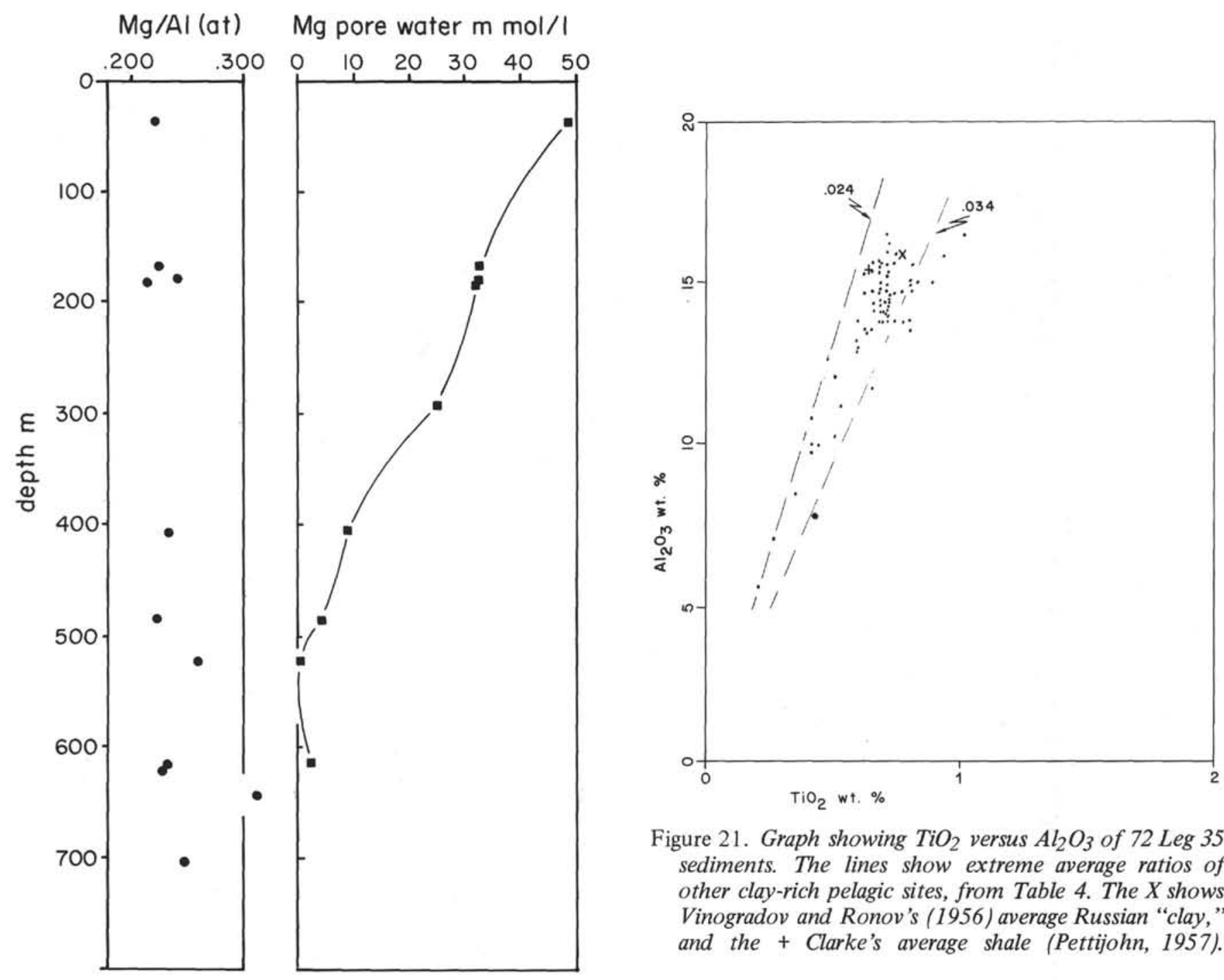

Figure 21. Graph showing $\mathrm{TiO}_{2}$ versus $\mathrm{Al}_{2} \mathrm{O}_{3}$ of $72 \mathrm{Leg} 35$ sediments. The lines show extreme average ratios of other clay-rich pelagic sites, from Table 4. The X shows Vinogradov and Ronov's (1956) average Russian "clay," and the + Clarke's average shale (Pettijohn, 1957).

Figure 20. Graph showing $\mathrm{Mg} / \mathrm{Al}$ (atomic) and $\mathrm{Mg}$ (pore water) versus depth for Site 325 . 